\title{
Study of spatiotemporal variation of atmospheric mercury and its human exposure around an integrated steel plant, India
}

\author{
S. Pervez ${ }^{1}$, A. Koshle ${ }^{1}$, and Y. Pervez ${ }^{2}$ \\ ${ }^{1}$ School of Studies in Chemistry, Pt. Ravishankar Shukla University, Raipur, CG, 492010, India \\ ${ }^{2}$ Department of Engineering Chemistry, Chhatrapati Shivaji Institute of Technology (CSIT), Kolihapuri, Pisegaon, \\ Durg, CG, 492010, India
}

Received: 29 September 2009 - Published in Atmos. Chem. Phys. Discuss.: 15 January 2010

Revised: 7 May 2010 - Accepted: 11 May 2010 - Published: 22 June 2010

\begin{abstract}
Mercury release by coal combustion has been significantly increased in India. Mercury content in coal has been analyzed to $0.272 \mathrm{ppm}$ by Central Pollution Control Board. Toxicological effects of elemental $\mathrm{Hg}\left(\mathrm{Hg}^{0}\right)$ exposure include respiratory and renal failures, cardiac arrest, and cerebral oedema, while subclinical exposure may induce kidney, behavioral, and cognitive dysfunctions. The present work is focused on dispersion pattern and interphase exchange phenomena of ambient mercury between air-particulate matter evaluations of alongwith dominance of various major routes of human exposure-dose response using regression analysis around an integrated steel plant in central India. Source-downwind type stratified random sampling plan using longitudinal study design has been adopted for ambient monitoring of total mercury, while representative sampling plant has been adopted for persona exposuredose response study In space-time framework. Control sites and subjects have been chosen from uncontaminated area (100 km away from any industrial activities). 06 ambient air monitoring stations and 17 subjects from workers, nonworkers but local residents' categories and from controlled sites have been chosen for the study. Samples of mercury biomarkers (blood, breast milk and urine) have also been collected from same subjects in each month during sampling period. The sampling period was March 2005 to February 2006 . Samples of $30 \%$ acidified $\mathrm{KMnO}_{4}$ for air-Hg absorption, $\mathrm{PM}_{10}$, RPM and biological samples were analyzed for total mercury by ICP-AES using standard methods. Local soils and ground water were also monitored for total mercury content during the sampling period. Results have shown that
\end{abstract}

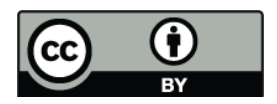

Correspondence to: $\mathrm{S}$. Pervez (shamshp@yahoo.co.in) mercury concentration is very high compared to prescribed limits in all receptors. Results of exchange phenomenon have shown the higher transfer of mercury from air to particulate during combustion in steel plant environment due to presence of huge amount of iron particles, in contrast to results obtained in other industrial locations earlier. Plant workers have shown 1.5 to 2.5 times higher personal RPM-Hg levels compared to Category 2 and 20-30 times higher than Category 3. All biomarkers have shown higher $\mathrm{Hg}$ presence compared to prescribed standards. Regression analysis between exposure routes and bio-receptors has been investigated. Dominance status of selected routes of bio-accumulation has been varied from category to category.

\section{Introduction}

Mercury has been recognized for decades as a persistent and bio-accumulative toxic substance in the environment (Sharma, 2002; Saleh et al., 2003 and Srivastava, 2003). The investigation of mercury behaviour is a field of particular concern due to its wide distribution in the different environmental compartments (Pirrone et al., 1996, 2003, 2001; Pacyna et al., 2001). Highly resolved spatial and temporal distributions of mercury emissions to the atmosphere from natural and anthropogenic sources are needed in global mass balance models, transport and deposition models, for relating mesoscale variations in mercury concentrations in both gas and particulate phase with regional and global circulation patterns, and in assessing the long-term ecological and health impacts on different environmental compartments(Cinnirella and Pirrone 2006; Pirrone et al., 1996, 2001, 2003; Pacyna et al., 2001). The ratio between the relative contributions of

Published by Copernicus Publications on behalf of the European Geosciences Union. 
natural and anthropogenic source categories may vary with region and time of the year. On global scale the contribution from industrial sources ranges between 1660 and $2200 \mathrm{t} \mathrm{yr}^{-1}$ (Pirrone et al., 1996; Pacyna et al., 2001, 2003), whereas emissions from natural sources (i.e., volatilization from water surfaces, volcanoes, re-emissions from topsoil and vegetation) may represent the major contribution (up to $60 \%$ of the total) to the global atmospheric mercury budget (Pirrone et al., 1996, 2001). It has been observed that the use of the amount of mercury mobilized and released into the atmosphere has increased compared to pre-industrial levels. Schuster et al. (2002) also reported a 20 -fold increase in atmospheric $\mathrm{Hg}$ deposition since pre-industrial times and that $70 \%$ of total $\mathrm{Hg}$ input was of anthropogenic origin in the last century. The processes involved in dynamics of atmospheric mercury on local, regional and global scale are atmospheric emissions, transport, wet and dry deposition, and gaseous mercury exchange at the various air-receptor (-water, -soil, -vegetation) interfaces (Mason et al., 1994; Pacyna and Keeller, 1995).

\subsection{Steel sector contribution in mercury emissions}

Asian countries contribute about $56 \%$ to the global emissions of mercury to the atmosphere with major emphasis on emission from stationary combustion sources including iron and steel production, thermal power plant and cement industries (Pacyna and Pacyna, 2002). Steel industries are known as one of the major consumer of coal, which is the chief source of mercury (Volkovic, 1983 and Airey, 1997). The integrated steel plants which composed of coke ovens, blast Furness and steel smelters are known for higher emissions of mercury with emission factor of $0.04 \mathrm{~g}$ per tonne of steel production in Asian countries(Borderieux et al., 2004; Pacyna and Pacyna, 2002; Pacyna, 1996; Themelis and Gregory, 2002). Around $31 \mathrm{Mg}$ of mercury per year are released to the environment and no major changes in the mercury emissions have been observed for this steel sector during the 1990's and beginning of 2000's. Asia $\left(14.4 \mathrm{Mg} \mathrm{y}^{-1}\right)$ and Europe $\left(12.5 \mathrm{Mg} \mathrm{y}^{-1}\right)$ are the most contributing regions to the global mercury budget from steel industries (Pacyna et al., 2006 and Pirrone et al., 2001). It has been reported that gaseous mercury has occupied major fraction of the anthropogenic part of the environmental mercury compared to inorganic and particulate mercury, while iron particles have been report to be best adsorbent of mercury vapor at high temperature (Borderieux et al., 2004; Pacyna and Pacyna, 2002). Mukherjee et al. (2008) have reported that annual mercury emission from iron and steel industries in India has been increased by a factor of 1.25 between yr 2000 and yr 2004. It has also been reported that fraction of total mercury emission from India by steel industries was also increased from $1.2 \%$ to $1.8 \%$ within this period.

\subsection{Mercury release in steel making}

In the 21 st century, crude steel production in India has increased from $26.9 \mathrm{Tg}$ in 2000 to $44.0 \mathrm{Tg}$ in 2006. Steel is manufactured mainly by integrated steel manufacturing processes using the chemical reduction of iron ore, and conversion of iron from the blast furnace in a basic oxygen furnace (BOF). Steel can also be produced by melting steel scrap (e.g. from shredded cars) in an electric arc furnace (EAF). Coke, necessary in the iron and steel industry, is obtained by coking in ovens at $1000^{\circ} \mathrm{C}$ or more. Here, $\mathrm{Hg}$ from coal is passed into the gas and other products of solid, liquid and gaseous by-product phases of the coking process. Coal consumption for the production of iron and steel in India accounts for about $13 \%$ of the total consumption i.e. $48.5 \mathrm{Tg}$ in 2004. The emission factor calculated for $\mathrm{Hg}$ emission is $0.08 \mathrm{~g} \mathrm{Mg}^{-1}$ crude steel which is quite realistic (Mukherjee et al., 2008a). It should be stated here that coke still contains a small amount of $\mathrm{Hg}$. Hence some $\mathrm{Hg}$ will pass into the atmosphere also from the sintering plant, blast furnace and steel production. Our emission factors are higher than the emission factors calculated by other authors. The simple reason for this is that the quality of coal in India is quite poor due to a high ash content (30-40\%-wt). For this reason, more coal is needed per $\mathrm{Mg}$ of steel production than in the USA or in Europe(Pirrone and Mason, 2008).

\subsection{Need of exposure-dose response study}

Personal respirable fine particulates (RPM) have shown significant potential to major pathways of atmospheric pollutants in human exposure assessment around industrial areas (Gadkari and Pervez, 2007). The human exposure routes of mercury has been found as: inhalation, consumption of water, consumption of fish, beef, cow's milk, poultry, chicken eggs, pork, lamb, green plants and ingestion of soil (Warner et al., 2008; Pirrone and Kathryn, 2005 and Roser MartiCid, 2008). It has been established that personal level represents the close relationship with human accumulation and epidemiology pattern of any region compared to other classified atmospheric receptors (USEPA, 2008). Most of the airparticulate mercury $\left(\mathrm{Hg}_{(g)}\right.$ and $\left.\mathrm{Hg}_{(p)}\right)$ has been quantified at ambient level and a strong variation in correlation of chemical character of particulate matter (PM) between ambient and personal levels has been reported (Meng et al., 2007; Sarnat et al., 2006). Longitudinal and pooled correlations between personal exposure and ambient or outdoor particulate matter (PM) concentrations varied considerably between study and study subjects. Most of studies that reported longitudinal correlation coefficients range from $<0$ to 0.1 , were indicating that an individual's daily activities pattern and residence type may have a significant effect on total personal exposure to PM. General population studies tend to show lower correlations because of the higher variation in the levels of PM 
generating activities (Adgate et al., 2007; Pellizzari et al., 2001; Rojas-Bracho et al., 2000; Linn et al., 1999).

\subsection{Human accumulation status}

Mercury is considered as a toxic trace element to humans, animals, and the ecosystem because of its unique geochemical characteristics (Drasch et al., 2004 and Li et al., 2006). Risk of mercury-associated adverse health effects are neuropsychological deficits in children and woman after in utero methylmercury $(\mathrm{MeHg}$ ) exposure (Kathryn et al., 2009). Blood Hg (BHg), Breastmilk-Hg (BM-Hg), urine- $\mathrm{Hg}$ and hair $\mathrm{Hg}$ concentrations are indicators of the magnitude of $\mathrm{MeHg}$ exposure (Adimado and Baah, 2002; Shrivastava, 2003). Mercury presence in human biomarkers and resulting health effects has been reported earlier (Kales and Goldman, 2002 and WHO, 2003). Bio intake of mercury using hair- $\mathrm{Hg}$ as human biomarker has been estimated tobe $6.780 \mu \mathrm{g} \mathrm{day}^{-1}$ in Changchun city, Northeast China ( $\mathrm{Li}$ et al., 2006). The association between elevated blood pressure and blood cadmium and mercury levels was examined (2001-2002) in 185 Saudi women. Blood mercury concentrations for hypertensives and controls were $3.506 \pm 3.617 \mu \mathrm{g} \mathrm{L}^{-1}$ and $3.687 \pm 3.186 \mu \mathrm{g} \mathrm{L}^{-1}$, respectively (Al-Saleh et al., 2006). Blood-Hg was also determined in 61 male and 40 female volunteers resident in Tehran (Iran) and found tobe $8.48 \pm 4.42 \mu \mathrm{g} \mathrm{L}{ }^{-1}$ (Farzin et al., 2008). 24 high school teachers from nine schools of Ohio were studied for mercury exposure through air and accumulation in voided urine samples. The median $\mathrm{Hg}$ concentration in 12 chemistry teachers was $4.6 \mu \mathrm{g} \mathrm{g}^{-1}$ creatinine (range 2.2$8.2 \mu \mathrm{g} \mathrm{g}^{-1}$ creatinine) and it was $6.3 \mu \mathrm{g} \mathrm{g}^{-1}$ creatinine in the 12 non-chemistry teachers. All classroom air samples contained mercury levels below detection limits (Crump et al., 1996). Breastfeeding for nursing infants, can be a potential source of exposure to toxic chemicals to which the mother has previously been exposed (Solomon and Weiss, 2002; Gundacker et al. 2002).

The work being presented here is focused on spatiotemporal variation of total atmospheric mercury alongwith its enrichment in personal particulates and human accumulation around an integrated steel plant in central India.

\section{Materials and methods}

\subsection{Study design}

Reports of significant release of mercury in the surrounding environment by high temperature processes (about $1000^{\circ} \mathrm{C}$ to $1250^{\circ} \mathrm{C}$ ) involved in major coal-fired industries (integrated steel plant) have put forward the need to evaluate spatial distribution pattern, seasonal variability and transportation routes of ambient mercury to personal level and human accumulation around the steel industrial location. The goal of the study is to assess spatiotemporal distribution pattern of atmospheric mercury and possible routes of human accumulation of environmental mercury in the vicinities of integrated steel plant with specific objectives are: 1 . To evaluate spatiotemporal variation of ambient mercury around selected industrial unit, 2. To assess exchange phenomena of mercury at air-particulate inter-phase, 3. Enrichment of ambient mercury in personal respirable fine particulates (RPM) and 4. Evaluation of relative dominance of identified routes of mercury in human biomarkers. Fourth objective has been chosen due to two reasons: 1 . previous reports of variation in correlation of classified atmospheric levels with human accumulation of air pollutants (USEPA, 2008) and, 2. Significant impact of secondary environmental receptors (soils and ground water) of anthropogenic mercury on human accumulation has been reported. Dietary habits and activity pattern of inhabitants are also the important factor in accumulation status of mercury.

\subsection{Sampling plan}

The spatial dimension covers the geographic scale and pattern of aerosols. Based on consideration of emissions, meteorology, and political boundaries, the spatial dimension can be broken into global, national, regional-synoptic, meso, urban, and local scales (USEPA, 1996). To achieve the objectives of the study around selected industrial units, a source-downwind receptor based longitudinal stratified random sampling plan for ambient monitoring and longitudinal representative sampling plan for personal particulates and human accumulation study programs (Gilbert, 1987) has been conducted around an integrated steel plant, Bhilai, District Durg, Chhattisgarh. Bhilai steel plant was located at global scale of Latitude- $21^{\circ} 11^{\prime} 0^{\prime \prime}$ and Longitude- $81^{\circ} 23^{\prime} 6^{\prime \prime} \mathrm{E}$. $3.41 \mathrm{Tg}$ of total saleable steel have been produced in Bhilai steel plant during 2002-2006. A total mass of approximate $1.317 \mathrm{Tg}$ of solid raw material is handled during the production of one $\mathrm{Tg}$ of steel. Raw material used in the production of one $\mathrm{Mg}$ of steel includes hot metal $(930.2 \mathrm{~kg})$, cold pig iron $(2.2 \mathrm{~kg})$, scrap iron $(34.1 \mathrm{~kg})$, scrap steel $(174.2 \mathrm{~kg})$, iron ore $(29.5 \mathrm{~kg})$, mill scale $(2.2 \mathrm{~kg})$, limestone $(51.4 \mathrm{~kg})$, lime $(13.7 \mathrm{~kg})$, fluorspar $(0.02 \mathrm{~kg})$, bauxite $(0.1 \mathrm{~kg})$, raw dolomite chips $(34.9 \mathrm{~kg})$, burnt dolomite $(19.1 \mathrm{~kg})$, magnesite $(8.2 \mathrm{~kg})$, ferrosilicon $(2.3 \mathrm{~kg})$, ferromanganese $(13.8 \mathrm{~kg})$, aluminium palettes $(0.26 \mathrm{~kg})$, iongot mould $(21.7 \mathrm{~kg})$, bottom stool $(8.4 \mathrm{~kg})$, and charing boxes $(0.577 \mathrm{~kg})$. About $1.41 \mathrm{Tg}$ of coal were consumed during the yr 2002-2006 for producing $3.41 \mathrm{Tg}$ of steel (BSP, 2008).

Previously reported meteorological records (wind direction, wind velocity, relative humidity and average rainfall), layout map, development plan, population density and human activity pattern of the study area has been utilized for the identification of sampling sites. Description of sampling sites around integrated steel plant has been presented in Table 1 alongwith location map and wind rose diagram (Figs. 1-2). Samples of gaseous mercury (Air-Hg) and $\mathrm{PM}_{10}$ 
Table 1. Description of sampling sites for environmental monitoring of mercury around integrated steel plant, Bhilai, India.

\begin{tabular}{|c|c|c|c|c|c|}
\hline S. No. & $\begin{array}{l}\text { Distance from } \\
\text { the plant }\end{array}$ & $\begin{array}{l}\text { Direction from } \\
\text { the plant }\end{array}$ & $\begin{array}{l}\text { Site characteristics in } \\
\text { relation to wind direction }\end{array}$ & $\begin{array}{l}\text { Wind } \\
\text { characteristics }\end{array}$ & $\begin{array}{l}\text { Site } \\
\text { name }\end{array}$ \\
\hline \multicolumn{6}{|c|}{ Integrated Steel Plant, Bhilai } \\
\hline 1 & $3 \mathrm{~km}$ & Southwest (SW) & Downwind & Calm and Clear & Maroda \\
\hline 2 & $5 \mathrm{~km}$ & Southwest (SW) & Downwind & Calm and Clear & Ruayabandha \\
\hline 3 & $3 \mathrm{~km}$ & West (W) & Down wind & Calm and Clear & Sector-4 \\
\hline 4 & $3 \mathrm{~km}$ & Northwest (NW) & Perpendicular to wind & Calm and Clear & Power House \\
\hline 5 & $3 \mathrm{~km}$ & Northeast (NE) & Downwind & Calm and Clear & Bhilai-3 \\
\hline 6 & $3 \mathrm{~km}$ & Southeast (SE) & Perpendicular to wind & Calm and Clear & Somani \\
\hline
\end{tabular}

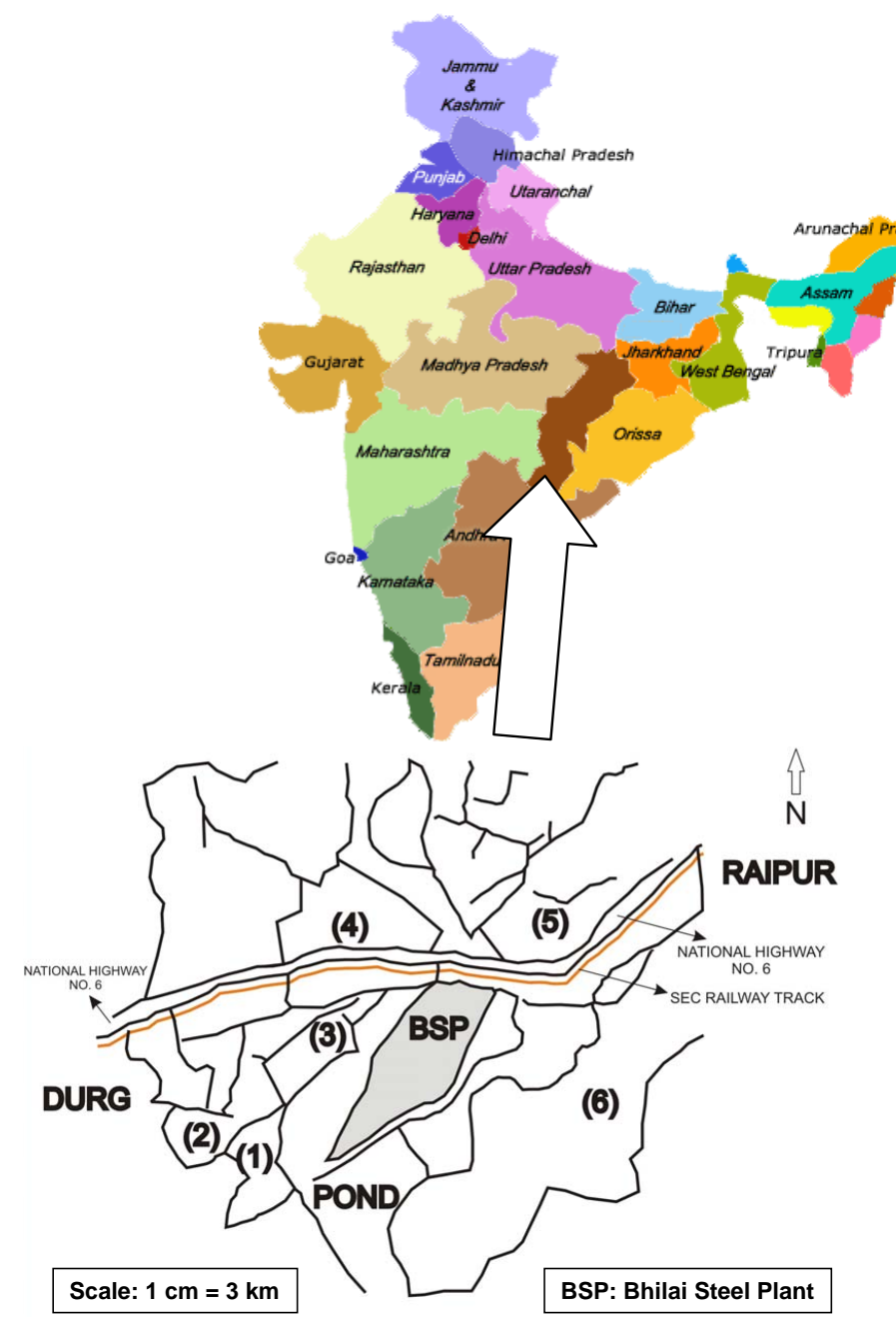

Fig. 1. Location map of air sampling sites for monitoring of ambient mercury around integrated steel plant, Bhilai, India.

for its mercury content $\left(\mathrm{PM}_{10}-\mathrm{Hg}\right)$ have been collected using two respirable dusts samplers (RDS) (Envirotech Model APM 410), Installed at a height of approximately 4-5 $\mathrm{m}$ from

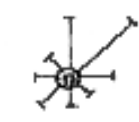

JANUARY (Calm $4, \mathrm{q}$ )
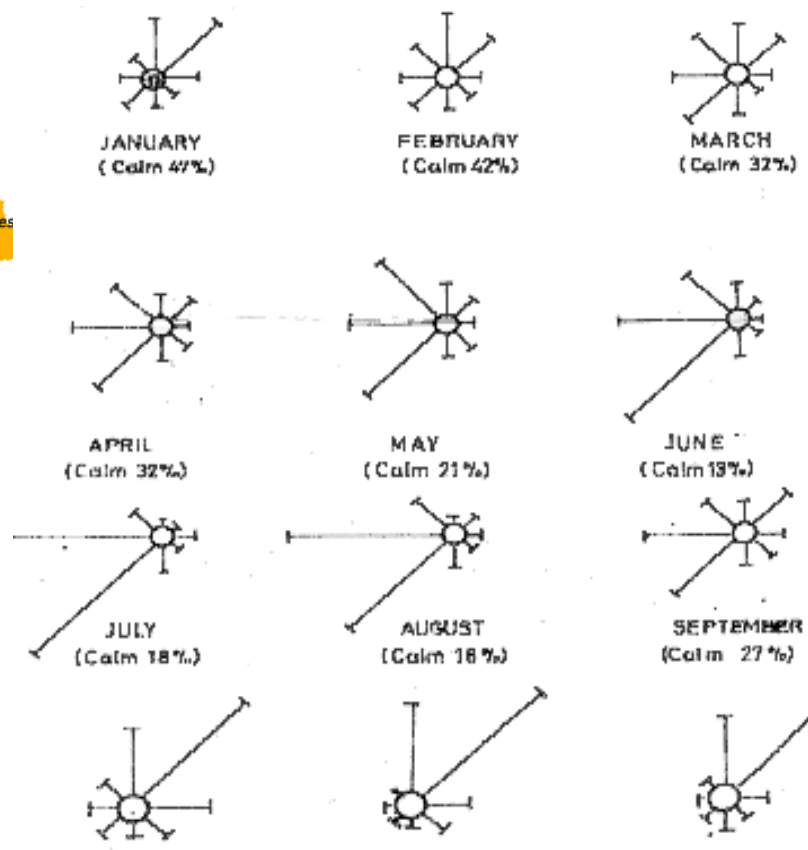

\section{OCTOGER}

(Calm 3/4\%)

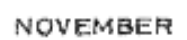

(Caim $46 \%$ )

Fig. 2. Wind rose diagram of Bhilai region during March 2005February 2006.

ground level. A 24-h sampling (8-hourly basis) has been conducted with an average air flow rate of $1.1 \mathrm{~m}^{3} / \mathrm{min}$. A total of 30 sampling session (24-hourly) have been conducted. Out of that 10 in each of three seasons (summer, post-rainy and winter) has been completed at each site throughout the sampling year (March 2005-February 2006). Glassfiber microfilter sheets have been used for $\mathrm{PM}_{10}$ sampling. Air samples have been collected in $30 \mathrm{~mL} 10 \%$ acidified $\mathrm{KMnO}_{4}$ solution, placed in three impingers connected in series. The trapping efficiency was reported to be better than $95 \%$ (Hacon et al., 1995 and Lu and Schroeder, 1999). Pre-weighed and calibrated glassfiber microfilter sheets (Whatman make) 
(GFF) (size $8^{\prime \prime} \times 10^{\prime \prime}$ ) for ambient monitoring has been used. The GFF were low resistance to airflow, a low affinity for moisture and $98 \%$ collection efficiency for particles of 0.5 micron or large size. The GFF were dried in an oven at 105$110^{\circ} \mathrm{C}$ for two hours and then equilibrated in conditioned environment (desiccators) for about three to five hours and then taken the weight of GFF to nearest milligram. All the samples of Ambient $\mathrm{PM}_{10}$ and gaseous mercury were transported and preserved in the laboratory as per laid down protocol (Envirotech, 2000 and Katz, 1977).

Personal exposure to respirable particulate matter (RPM) (size less than 5 micron) has been monitored using integrated personal exposure monitoring protocol. For the purpose of personal sampling, a representative sampling plan using longitudinal study design has been adopted. 100 subjects were identified on the basis of their direct or indirect relation with steel plant using a questionnaire, which include their gender, age, occupation, and health status, dietary habits and timeactivity pattern. After formal consent of subjects for participation in the study, 17 subjects have been grouped in three categories: 1. Subjects who are the plant workers and residing in plant township, 2. Subjects who are non-plant workers but residing in township and 3. Subjects who are nonplant workers and residing in uncontaminated area (Subjects of control site) (100 km approx. away upwind from any industrial activity) (USEPA, 2003; Gilbert, 1987). All subjects were belonging to non-vegetarian category and consumer of fresh water fishes like carp fishes (Labeo rohita, Katla) frequently. Amalgam filling case has not been reported in any subject. Details of subject selection and their personal RPM levels have been presented in Table 4. Similar subjects have given consent to participate in biological sampling of blood, urine and breast milk.

Two personal samplers with attached cyclonic assembly (particle cut off size: 5 micron and less) (Envirotech, Model APM 801) with an average flow rate of $1.0 \mathrm{~L} \mathrm{~min}^{-1}$ have been used for measurements of personal RPM. In case of 24$\mathrm{h}$ integrated personal exposure sampling, each subject was monitored for $24 \mathrm{~h}$ in a $48 \mathrm{~h}$ sampling session. $8-10$ sampling sessions have been completed on each subject throughout the sampling period (Gilbert, 1987; Envirotech, 2000; USEPA, 2002, 2008). Glass fiber microfilter sheets (GFF) (size: dia$37 \mathrm{~mm}$ ) (Whatman Make) have been used for the collection of RPM. Most of earlier studies conducted with objective of personal exposure assessment were focused on exposuredose response pattern. It has been decided to perform preliminary observations about accumulation status of mercury in selected human biomarkers viz blood, urine and breast milk of selected subjects for exposure study. Samples of biological fluids (blood, urine and breast milk) have been collected with the help of pathologists working at local health center as per medical protocol of sampling. $10 \mathrm{~mL}$ of blood samples of subjects have been collected using disposable syringes (Dispovan Make) and transferred to $25 \mathrm{~mL}$ glass bottles. Urine samples ( $25 \mathrm{~mL}$ approximately) have been collected in morn- ing (blank stomach) and in afternoon (after lunch). Both urine samples were mixed together to avoid variation in daily urine- $\mathrm{Hg}$ concentration. $20 \mathrm{~mL}$ of breast milk samples of feeding mothers have also been collected with the help of suction pump provided by health centers. All samples were stored at temperature of $4{ }^{\circ} \mathrm{C}$ (Adimado and Baah, 2002). About 6-8 sampling sessions (monthly/bimonthly) of biological fluids have been conducted on each subject throughout the sampling period of ambient air.

\subsection{Sample preparation and analysis}

Four circles (one inch diameters) were punched out from each of three exposed GFFs of 24-h sampling for ambient $\mathrm{PM}_{10}$ and complete GFFs of personal RPM were taken in the Teflon digestion bombs, separately, followed by the addition of $10 \mathrm{~mL}$ acid mixture of $\mathrm{H}_{2} \mathrm{O}_{2}: \mathrm{HNO}_{3}$ at ratio of $1: 3$ and placed in an oven at $180^{\circ} \mathrm{C}$ for six hours (Richard, 1970; Envirotech, 2000; Lu and Schroeder, 1999). Samples of blood, urine and breast milk have been digested using standard reported protocol (Adimado and Baah, 2002; Saleh et al., 2003; Walcher, 1963). The digested samples of ambient $\mathrm{PM}_{10}$, personal RPM, Air-Hg (30 mL of $10 \%$ acidified $\mathrm{KMnO}_{4}$ ), and human biological fluids were subjected to chemical analysis using ICP-AES (JOBIN-YVON HORIBA Ultima 2, ICP Spectrometer Version 3.0) with a lower detection limit of $1.0 \mu \mathrm{g} \mathrm{L}{ }^{-1}$. An Argon gas with ionization energy of $15.6 \mathrm{eV}$ has been used as plasma. Mercury analysis has been carried out at a wavelength of $194.227 \mathrm{~nm}$ to avoid interferences. Calibration of the instrument has been done using mercury chloride (AR, Merck) of concentration range 0.001-0.1 ppm (Montaser and Golightly; 1987). 4-5 measurements have been done in each sample to maintain relative standard deviation within $5 \%$.

\subsection{Data analysis and documentation}

Data of mercury measured at ambient and personal levels have been summarized as mean \pm standard deviation of longitudinal measurements and presented alongwith other statistical parameters (spatial variability, correlation coefficient of RPM-Hg with ambient $\mathrm{Hg}$ ) in Tables 2 and 4 and Fig. 3. Exchange phenomena and correlation studies of mercury data between air-particle inter-phases has been assessed using regression analysis (USEPA, 2003). It has been reported that intercept values of regression analysis have shown clear agreement with concentration of specific pollutant generated in dependent environmental receptors itself with respect to independent receptors and slope values have shown removal of pollution concentration from dependent receptors (Geller et al., 2002; Gadkari and Pervez, 2006). Regression analysis has been conducted between $\mathrm{PM}_{10}$ and $\mathrm{PM}_{10}-\mathrm{Hg}$ alongwith Air- $\mathrm{Hg}$ and $\mathrm{PM}_{10}-\mathrm{Hg}$. Spatial variability has been calculated using statistical tools (Roosli, 2000). Results have been presented in Fig. 4. 
Table 2. Annual average $\left(\mu \mathrm{g} \mathrm{m}^{-3}\right)$ and statistical data of ambient $\mathrm{PM}_{10}$ and $\mathrm{Hg}$ concentration around an integrated steel plant, Bhilai during March 2005-February 2006.

\begin{tabular}{|c|c|c|c|c|c|c|c|}
\hline \multirow[t]{2}{*}{ Parameters } & \multicolumn{6}{|c|}{ Site numbers } & \multirow{2}{*}{$\begin{array}{l}\text { Spatial } \\
\text { variability } \\
(\mathrm{CV})(\%)\end{array}$} \\
\hline & 01 & 02 & 03 & 04 & 05 & 06 & \\
\hline Air-Hg level & $0.53 \pm 0.37$ & $0.17 \pm 0.15$ & $0.64 \pm 0.38$ & $0.87 \pm 1.85$ & $1.83 \pm 5.07$ & $0.14 \pm 0.05$ & 88.85 \\
\hline $\mathrm{PM}_{10}$ level & $370.41 \pm 68.13$ & $166.19 \pm 81.06$ & $352.86 \pm 140.60$ & $475.71 \pm 232.95$ & $669.64 \pm 123.95$ & $92.85 \pm 43.44$ & 58.90 \\
\hline $\mathrm{PM}_{10}-\mathrm{Hg}$ level & $8.76 \pm 9.85$ & $5.16 \pm 6.77$ & $13.47 \pm 5.75$ & $14.02 \pm 4.86$ & $24.37 \pm 7.95$ & $2.27 \pm 1.82$ & 69.22 \\
\hline Total ambient $\mathrm{Hg}$ level & $9.35 \pm 9.91$ & $5.39 \pm 6.88$ & $14.13 \pm 6.16$ & $15.54 \pm 6.14$ & $27.24 \pm 11.88$ & $2.47 \pm 1.88$ & 71.49 \\
\hline Air- $\mathrm{Hg} / \mathrm{PM}_{10}-\mathrm{Hg}$ & 0.06 & 0.03 & 0.05 & 0.06 & 0.07 & 0.06 & 25.45 \\
\hline
\end{tabular}

(a)

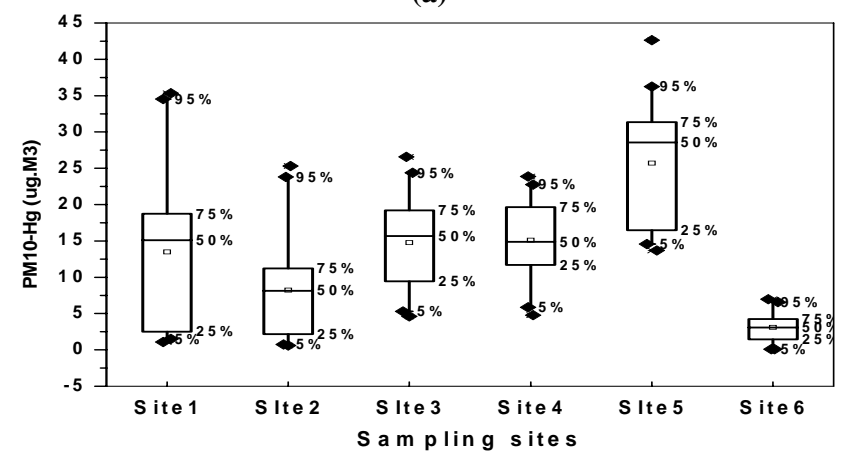

(b)

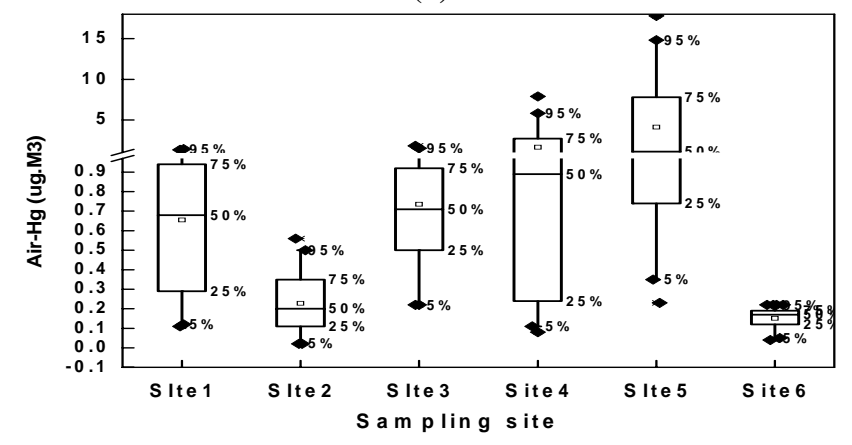

Fig. 3. Annual statistical box plots of ambient $\mathrm{PM}_{10}$ (a) and Air$\mathrm{Hg}$ levels measured at selected sites around an integrated steel plant Bhilai during March 2005-February 2006.

Temporal variability is another important factor in characterizing the dispersion pattern of mercury in time scale. Most of the temporal studies conducted earlier were based on time scale: Hourly, daily, seasonal and yearly (USEPA, 2008). In most of the reported studies, seasonality is coupled with spatial variability for air pollution dispersion assessment. Measurements of air pollutants in identified and defined periods have been documented in the form of statistical graphs in most of previous studies for assessment of temporal variation (Fitz-Simons et al., 2000). The study design has been planned using defined criteria of assessment of temporal variation of air pollution around single source in regional scale. The specified criteria has edict the requisition of measurements of atleast 15 days in each calendar quarter of either a three year or two year period at two or three monitoring sites (Rizzo and Pinto, 2001). Monitoring of ambient mercury in multiple sites around stationary industrial sources has been decided on account of assessment of temporal variation in more than two yearly monitoring programs. Previous monitoring programs of yr 1996 and 2000 have been selected alongwith present study for assessment of temporal variation. Data of ambient $\mathrm{PM}_{10}-\mathrm{Hg}$ has been utilized for assessment of temporal variation due to lack of Air- $\mathrm{Hg}$ data during previous sampling programs.

Data of all selected monitoring programs have been presented in statistical box plot graphs (Fig. 5). A nonparametric statistical test has been applied to compare means of selected programs due to non-Gaussian distribution of environmental data. Kruskall-Wallis test has been applied for more than two monitoring programs (Helsel and Hirsch, 1992). Kruskal-Wallis test (KW) tests the hypothesis of homogeneity i.e. if there are significant differences in the space or in time. It is the robust test for multiple comparisons when the sample sizes are unequal. All tests were performed at the 5\% significance level. These tests give chi-square approximation at high satisfactory level (Conover, 1999). Results have been presented in Table 3.

Mercury data of human biomarkers have been presented in Fig. 6. Inter-correlations of $\mathrm{Hg}$ data between selected human biomarkers have been presented in Table 5. Regression analysis between selected exposure routes (ambient-Hg, personal RPM-Hg, ground water-Hg and soil-Hg) with mercury levels of human biomarkers has been conducted to assess contribution estimates of bio-mercury through selected environmental routes. The results have been presented in Table 6 .

\section{Results and discussion}

Discernible reception pattern of mercury in air-particulate matrices of ambient level around integrated steel plant has been observed from the outcome of data analysis. The observed pattern is might be due to processes involved 

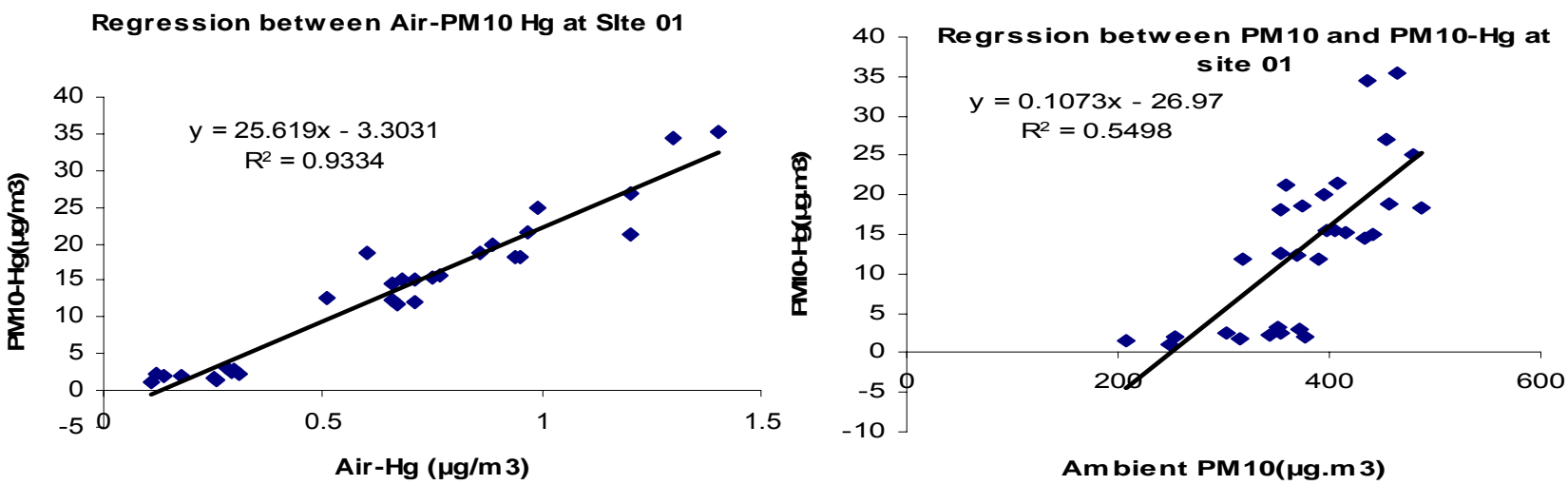

Regression between Air and PM10 $\mathrm{Hg}$ at site 02
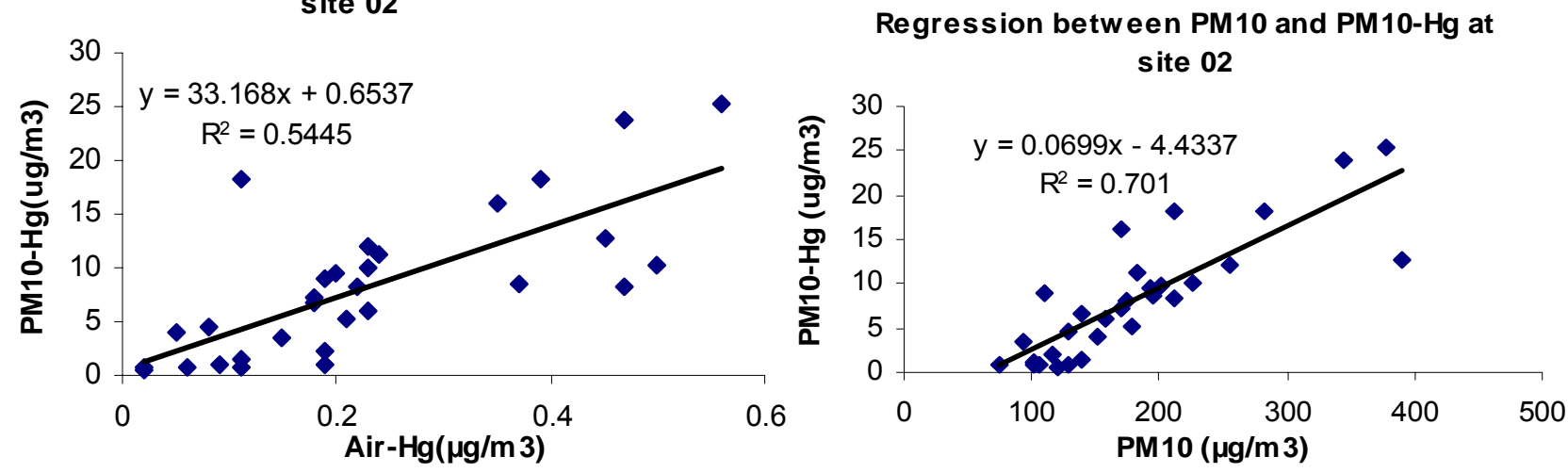

Regression between Air-Hg and PM10-Hg at site 03
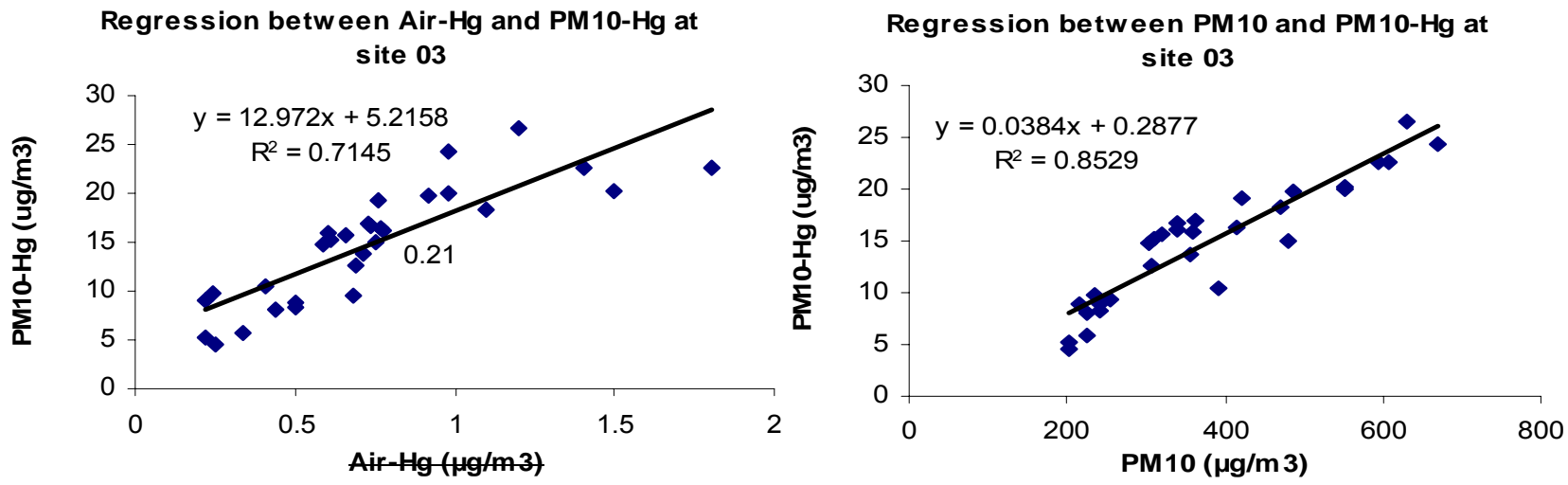

Fig. 4. Regression graph of selected measurements of $\mathrm{PM}_{10}, \mathrm{PM}_{10}-\mathrm{Hg}$ and Air-Hg at identified sites around steel plant, Bhilai.

in different units of steel plant (coke ovens, steel melting shops, blast furnace). Meteorological parameters, other local/temporary sources of mercury emissions and presence of catalytic metal particles in air media were played important role in enrichment of mercury at personal RPM levels. Multi-complexity in types of source contribution is resulting in variation of dominating routes of mercury accumulation in human biomarkers around such industrial units. On the basis of objectives, results are explained as follows:

\subsection{Statistical inferences of ambient mercury levels}

Significantly higher concentration (annual geometric mean) of ambient $\mathrm{PM}_{10}$ and its $\mathrm{Hg}$ content alongwith Air-Hg levels has been observed and exceeding the prescribed limits of $\mathrm{PM}_{10}\left(60 \mu \mathrm{g} \mathrm{m}^{3}\right), \mathrm{PM}_{10}-\mathrm{Hg}\left(0.003 \mu \mathrm{g} \mathrm{m}^{-3}\right)$ and Air$\mathrm{Hg}\left(0.012 \mu \mathrm{g} \mathrm{m}^{-3}\right)$ proposed by Central Pollution Control Board of India (CPCB) (Table 2 and Fig. 3) (CPCB, 2008). $\mathrm{PM}_{10}$ levels have been evaluated to be 2.9-11 times higher than prescribed standards for $\mathrm{PM}_{10}$. Annual average of Air$\mathrm{Hg}$ levels have shown significantly lower trend compared to $\mathrm{PM}_{10}-\mathrm{Hg}$ levels across all sites (range in terms of air$\mathrm{Hg} / \mathrm{PM}_{10}-\mathrm{Hg}$ ratio: $\left.0.03-0.07\right)$. This pattern of occurrence 
Regression between Air-Hg and PM10-Hg at site 04
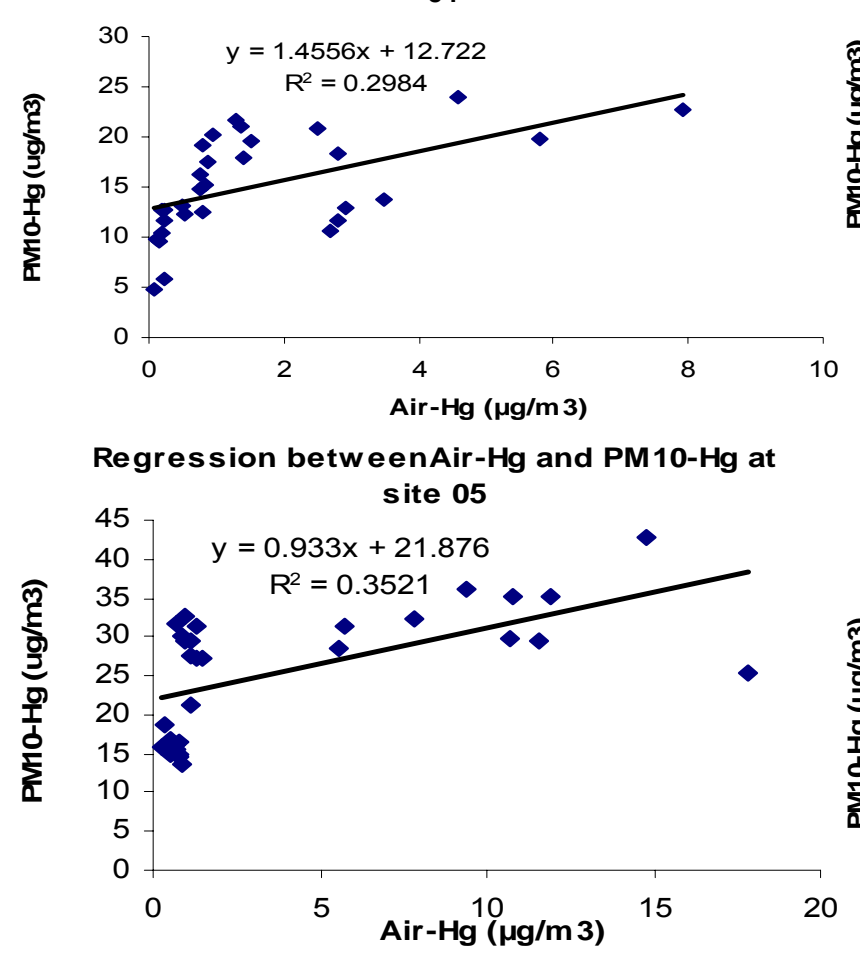

Regression between Air-Hg and PM10-Hg at

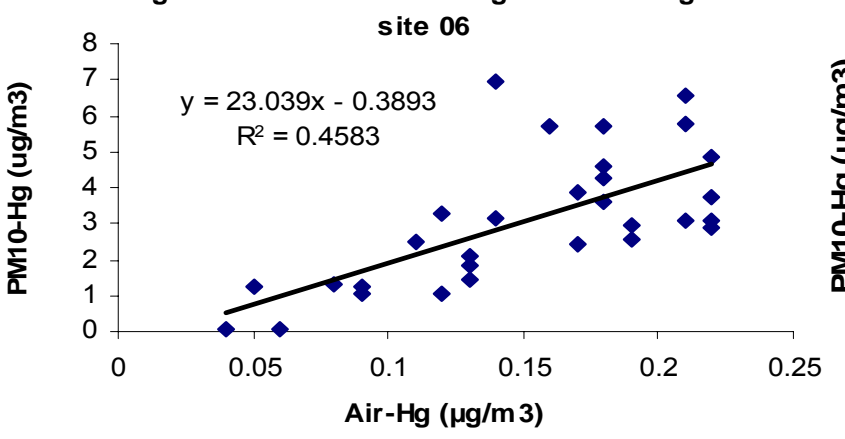

Regression between PM10 and PM10-Hg at site

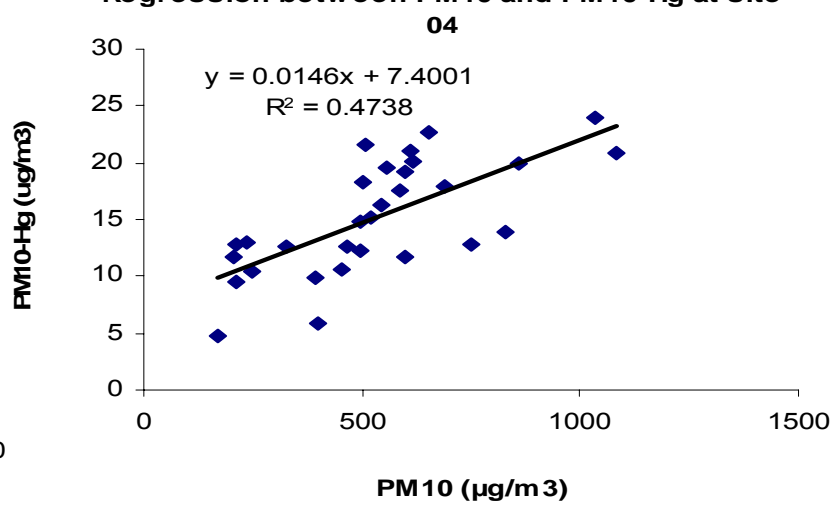

Regression between PM10 and PM10-Hg at site 05

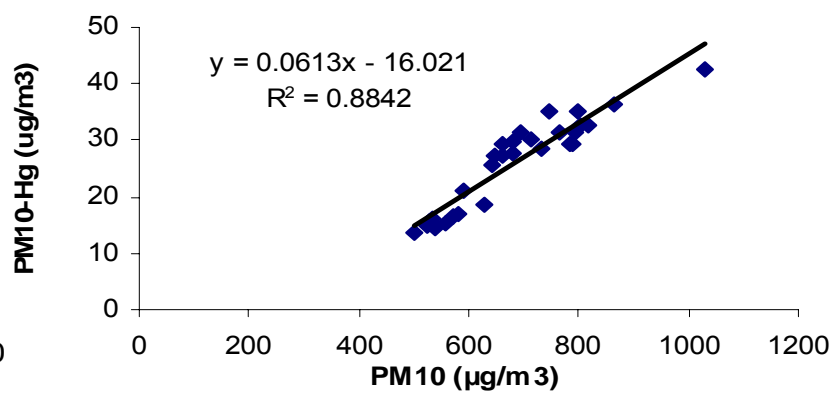

Regression between PM10 and PM10-Hg at site 06

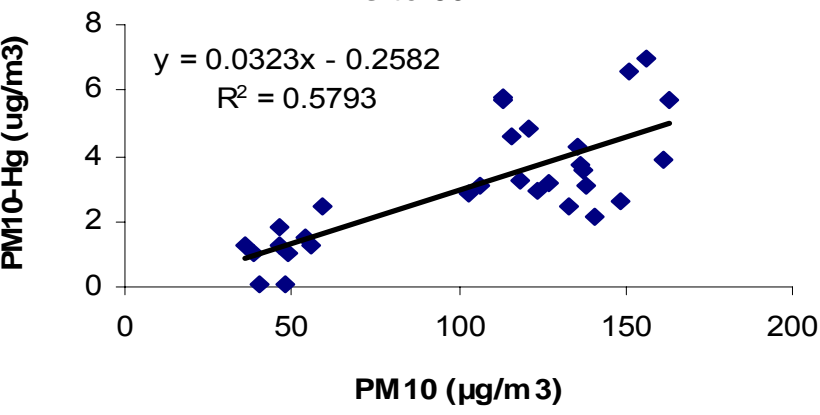

Fig. 4. Continued.

is contrast to previous reported ambient $\mathrm{Hg}$ levels monitored in various urban areas (Pacyna and Pacyna, 2002). Role of metal oxides especially $\mathrm{Fe}_{2} \mathrm{O}_{3}$ has shown strong absorption capacity for vapour-Hg/elemental-Hg by converting it to inorganic mercury ions. Conversion is enhanced in presence of other catalytic metal oxides in presence of nitrogen oxides (Borderieux, 2004). Prevailing wind sites (Site No. 1 and 5) have shown similar pattern of deviation from annual mean data of $\mathrm{PM}_{10}$. Higher values of $\mathrm{PM}_{10}$ at Site No. 5 compared to Site No. 1 are due to fact that percentage of prevailing wind from the plant was more favorable to Site No. 5 compared to Site No. 1 It has also been evaluated that deviation in the annual measurements of $\mathrm{PM}_{10}$ at prevailing wind sites is
2.1-2.3 times less than that obtained at other sites. Site No. 3 and 4 located across the wind direction have shown higher levels of $\mathrm{PM}_{10}$ due to their close proximity ( $2 \mathrm{~km}$ away from the plant premises) and station of other local sources of dust emissions (Highway, municipal waste burning etc.).

All sampling sites have shown higher levels of Air- and $\mathrm{PM}_{10}-\mathrm{Hg}$ compared to proposed standards by CPCB (Fig. 3 ). Different pattern of deviation from annual mean data of Air$\mathrm{Hg}$ has been observed across the sites. Site No. 1, 4 and 6 have shown lower trend of deviation from mean data compared to other sites. High standard deviation from mean value of Air-Hg at Site No. 5 has explained the possibility of another potential source of mercury at this place. Site 
Maroda(Site No. 1) (Downwind)

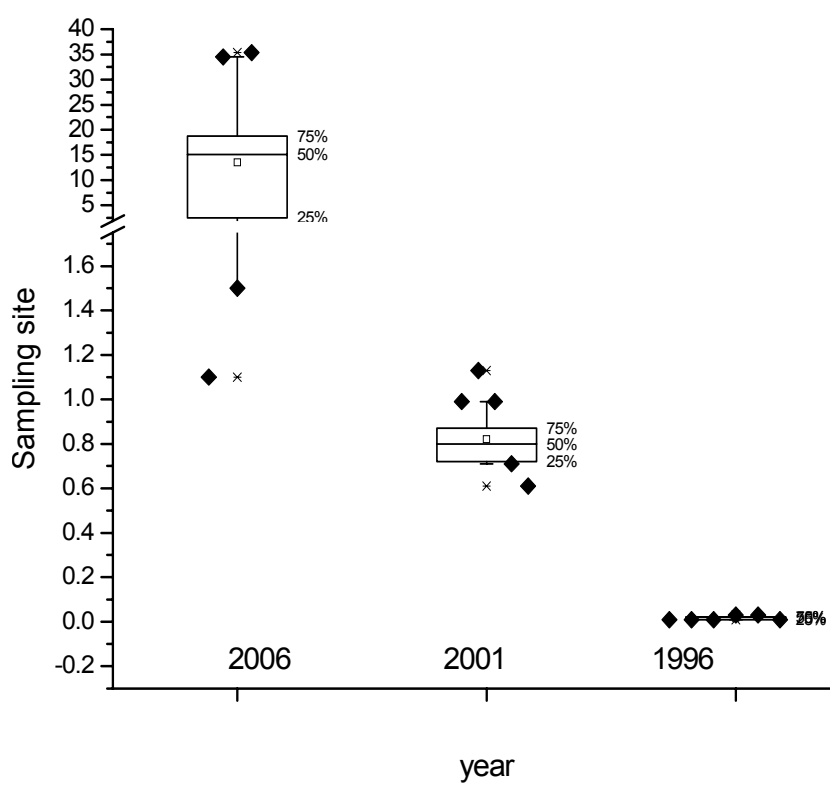

Power House (Site No. 4) (across wind)

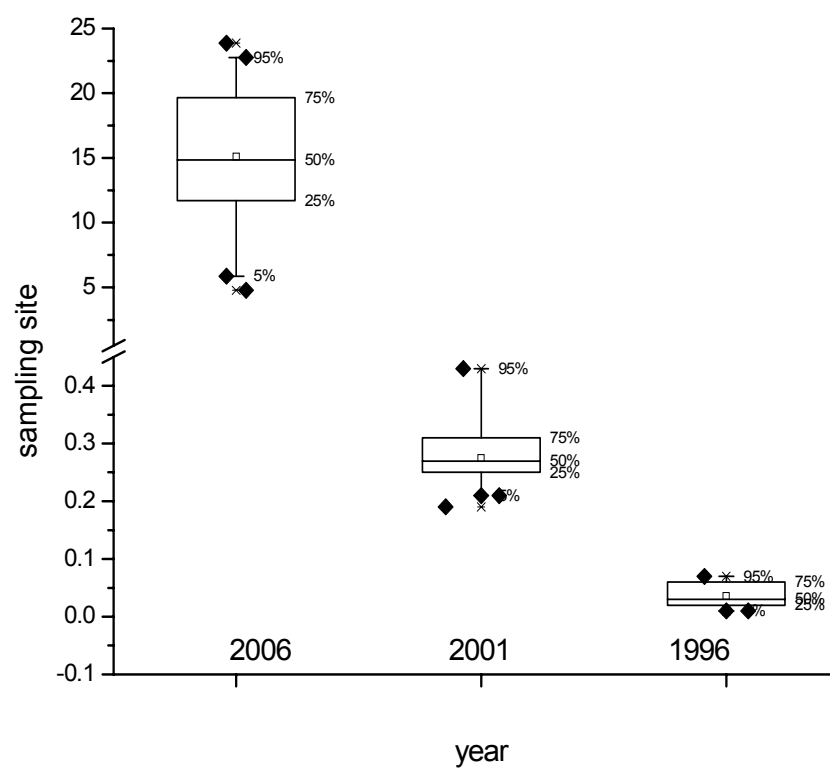

Ruabandha (Site No. 2) (Control)

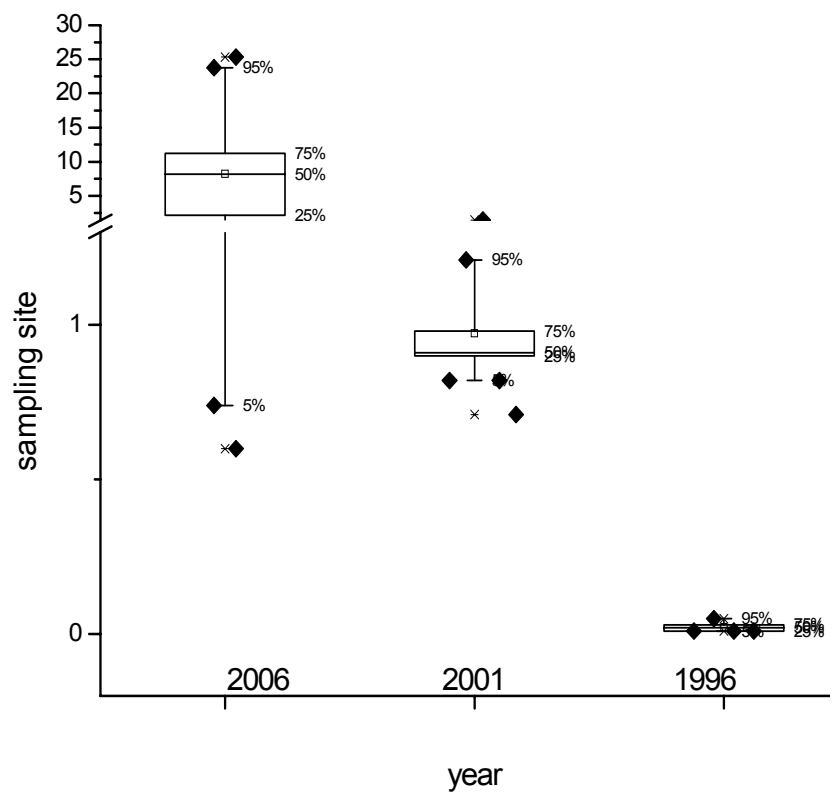

Bhilai-3 (Site No. 5) (Downwind)

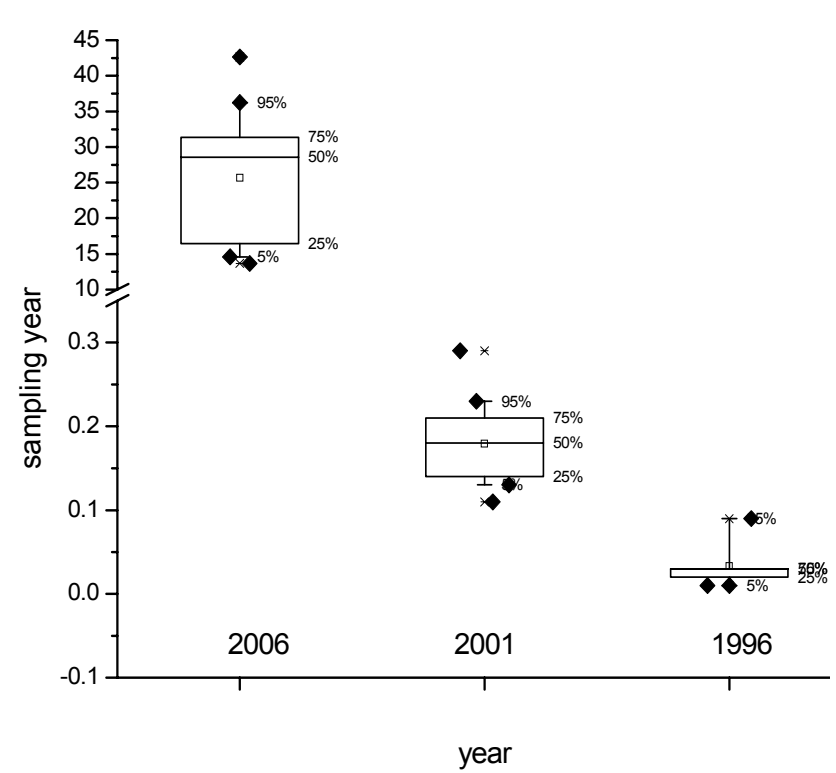

Fig. 5. Temporal variation of Total Ambient $\mathrm{Hg}$ in selected monitoring programs around Steel plant, Bhilai, India.

No. 1 and 2 has shown more than 100\% deviation from mean data of $\mathrm{PM}_{10}-\mathrm{Hg}$, while other sites have shown lower trend of deviation pattern. In case of Site No. 1, both Air-Hg and $\mathrm{PM}_{10}-\mathrm{Hg}$ has shown similar pattern of variation throughout the sampling period, which indicate the possibility of single source of origin. It is different in case of another prevailing wind site (Site No. 5) where $50^{\mathrm{TH}}$ percentile is inversely projected from mean in box plot statistical graph. Outliers for $\mathrm{PM}_{10}-\mathrm{Hg}$ have been projected close to the $95^{\mathrm{TH}}$ percentile levels across all sites except Site No. 5, while it was away from $95^{\mathrm{TH}}$ percentile of Air-Hg in case of Site No. 4 where multiplicity of sources of $\mathrm{Hg}$ emission has been observed. Statistical mean of $\mathrm{PM}_{10}-\mathrm{Hg}$ has been projected below $50^{\mathrm{TH}}$ percentile, while it was projected at higher side for Air-Hg in both prevailing sites (1 and 5). 


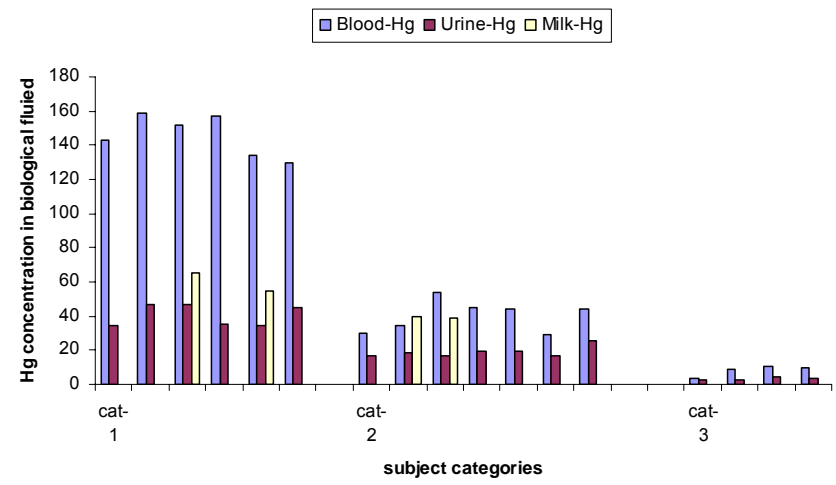

Fig. 6. Mercury levels $\left(\mu \mathrm{g} \mathrm{L}{ }^{-1}\right)$ in selected biomarkers of identified subject categories around an integrated steel plant.

\subsection{Exchange phenomena of ambient mercury in air-particulate inter-phases}

Regression analysis between $\mathrm{PM}_{10}$ and $\mathrm{PM}_{10}-\mathrm{Hg}$ alongwith $\mathrm{PM}_{10}-\mathrm{Hg}$ and Air-Hg has been presented in Fig. 4. Intercept values of regression analysis has explained the contribution of independent variable to dependent variable (Geller et al., 2002). Due to previous reports of air as principal ambient receptor of mercury emitted from industrial combustion processes (Carpi, 1997), Air-Hg is taken as independent variable in regression between Air- $\mathrm{Hg}$ and $\mathrm{PM}_{10}-\mathrm{Hg}$. It has been clearly observed in Site No. 1 (prevailing wind site) that Air- $\mathrm{Hg}$ has not contributed to $\mathrm{PM}_{10}-\mathrm{Hg}$ due to negative intercept value and justify the particulate mercury is generated during combustion process in the plant. In case of other sites including another prevailing Site No. 5, Air-Hg has shown significant contribution to $\mathrm{PM}_{10}-\mathrm{Hg}(10.25 \%)$ with positive intercept value. Occurrence of this pattern at Site No. 5 might be due to station of other sources of air- $\mathrm{Hg}$ emissions and it can also be explained by $r^{2}$ values of regression between $\mathrm{PM}_{10}$ and $\mathrm{PM}_{10}-\mathrm{Hg}$ which is higher at Site No. 5 compared to another prevailing wind Site No. 1. Higher presence of catalytic iron particles at Site No. 3 is responsible for higher conversion at this site (Borderieux, 2004 and Sharma 2002). Site No. 3 has shown higher positive $r^{2}$ values due to its close proximity to the plant and has shown $61.32 \%$ contribution of Air- $\mathrm{Hg}$ to $\mathrm{PM}_{10}-\mathrm{Hg}$ at this site. It is low in case of Site No. 4 $(9.27 \%)$ due to less mass inflow of iron particles towards this site. It can also be justifiable by the intercept values of Air$\mathrm{Hg}$ and $\mathrm{PM}_{10}-\mathrm{Hg}$ regression at Site No. 3 has shown higher contribution from Air-Hg to $\mathrm{PM}_{10}-\mathrm{Hg}$ due to multiplicity of local sources of emission.

\subsection{Spatiotemporal variation pattern of ambient mercury}

Spatial variability and distribution pattern across the sites has been presented in Table 2. Highest spatial variability has been obtained for Air-Hg levels (88.85\%). $\mathrm{PM}_{10}$ and $\mathrm{PM}_{10^{-}}$ $\mathrm{Hg}$ levels have shown comparable values of spatial variabil-
Table 3. Results of Kruskal wallis multiple comparison test of yearly difference ambient mercury around integrated steel plant, Bhilai, India.

\begin{tabular}{llll}
\hline Area & Test period & \multicolumn{2}{c}{$\mathrm{PM}_{10}-\mathrm{Hg}$} \\
\hline \multirow{3}{*}{ Overall } & $2006-2001$ & 53.02 & Mean difference* \\
& $2001-1996$ & 55.07 & 0.0001 \\
& $2006-2001$ & 2.05 & 0.0001 \\
Site1 & $2006-1996$ & 8.75 & 0.0001 \\
& $2001-1996$ & 0.8 & 0.0001 \\
& $2006-2001$ & 4.21 & 0.0001 \\
Site2 & $2006-1996$ & 5.14 & 0.0003 \\
& $2001-1996$ & 0.93 & 0.0015 \\
& $2006-2001$ & 13.86 & 0.0001 \\
Site4 & $2006-1996$ & 13.99 & 0.0002 \\
& $2001-1996$ & 0.13 & 0.0001 \\
& $2006-2001$ & 27.02 & 0.0001 \\
Site5 & $2006-1996$ & 27.2 & 0.0005 \\
& $2001-1996$ & 0.18 & 0.0001 \\
& & & 0.0001 \\
\end{tabular}

*Mean values in $\mu \mathrm{g} \mathrm{m}^{-3}$ (n.s. $=$ non significant at $\alpha=0.05$ ).

ity. Total ambient $\mathrm{Hg}$ (Ambient air-Hg+Ambient $\mathrm{PM}_{10}-\mathrm{Hg}$ ) has shown comparable spatial variability with Air-Hg levels. The spatial distribution pattern is similar for all mercury levels measured in selected ambient matrices. Annual measurements of total mercury in selected sampling programs for investigation of temporal variation has been presented in Fig. 5. Ambient $\mathrm{PM}_{10}-\mathrm{Hg}$ around steel plant, Bhilai has been increased by a factor of 26 during 2001-2006 compared to 1996-2001 with a significance level of 0.0001. This might be due to sharp increase in consumption of mercury bearing ingredients of raw material during this period. Mean difference of 53.02 has been obtained from yr 2001 to 2006, while it was 2.05 from yr 1996 to 2001 with a significance level of 0.0001 using Kruskal Wallis test Table 3.

\subsection{Personal exposure and human accumulation pattern of mercury}

Subjects of Category 1 and 2 have shown higher personal RPM levels compared to proposed prescribed standards of $\mathrm{PM}_{10}\left(60 \mu \mathrm{g} \mathrm{m}^{-3}\right)$ in context to the reported ratio of $\mathrm{PM}_{10} / \mathrm{RPM}$ earlier in the study region (Table 4) (Brook et al., 1997). RPM $\left(\mathrm{PM}_{5}\right) / \mathrm{PM}_{10}$ ratio has been evaluated to be in the range of 0.36-0.62 (Gadkari and Pervez, 2007). Plant workers have shown 1.5 to 2.5 times higher RPM$\mathrm{Hg}$ levels compared to Category 2 and 20-30 times higher than Category 3. All RPM-Hg levels are exceeding very high compared to proposed permissible level of particulate$\mathrm{Hg}$ by CPCB $\left(0.003 \mu \mathrm{g} \mathrm{m}^{-3}\right)$. Category wise subjects belong to plant workers have shown 2-3 times higher levels of RPM-Hg compared to Category 2 and 20-40 times higher 
Table 4. Average integrated personal exposure of $\mathrm{Hg}$ levels (RPM-Hg) and its correlation with ambient PM10-Hg around integrated steel plant, Bhilai.

\begin{tabular}{|c|c|c|c|c|c|}
\hline Category of subject & S. No. & $\begin{array}{l}\text { No and type subject } \\
\text { (age/sex/smoker/oc)* }\end{array}$ & $\operatorname{RPM}\left(\mu \mathrm{g} \mathrm{m}^{-3}\right)$ & RPM-Hg $\left(\mu \mathrm{g} \mathrm{m}^{-3}\right)$ & $R \mathrm{Hg}\left(\mathrm{PM}_{10}\right)^{-\mathrm{Hg}_{(\mathrm{RPM})}}$ \\
\hline \multirow{6}{*}{ Cat-1 } & 1 & $30 / \mathrm{m} / \mathrm{x} / \mathrm{pw}$ & $710.12 \pm 10.05$ & $39.1 \pm 16.22$ & 0.33 \\
\hline & 2 & 40/f/x/pw & $634.64 \pm 11.98$ & $30.46 \pm 11.51$ & 0.65 \\
\hline & 3 & $22 / f / x / p w$ & $1038.16 \pm 13.23$ & $44.23 \pm 12.34$ & 0.25 \\
\hline & 4 & $27 / \mathrm{m} / \sqrt{ } / \mathrm{pw}$ & $915.09 \pm 9.16$ & $37.45 \pm 4.36$ & 0.69 \\
\hline & 5 & $31 / f / x / p w$ & $425.61 \pm 15.18$ & $25.4 \pm 14.42$ & 0.62 \\
\hline & 6 & $32 / \mathrm{m} / \sqrt{ } / \mathrm{pw}$ & $562.45 \pm 12.56$ & $27.49 \pm 10.6$ & 0.76 \\
\hline \multirow{7}{*}{ Cat-2 } & 7 & $32 / \mathrm{m} / \sqrt{ } /$ shopkeeper & $594.16 \pm 7.29$ & $17.82 \pm 8.13$ & 0.79 \\
\hline & 8 & 26/f/x/teacher & $503.05 \pm 14.69$ & $24.60 \pm 12.67$ & 0.62 \\
\hline & 9 & 25/f/x/hw & $412.59 \pm 10.12$ & $17.33 \pm 7.78$ & 0.89 \\
\hline & 10 & 26/f/x/hw & $345.61 \pm 8.72$ & $6.55 \pm 3.64$ & 0.6 \\
\hline & 11 & $35 / \mathrm{m} / \sqrt{ } / \mathrm{w}$ & $470.11 \pm 9.65$ & $10.83 \pm 6.30$ & 0.9 \\
\hline & 12 & $26 / \mathrm{m} / \sqrt{ } / \mathrm{w}$ & $510.43 \pm 7.39$ & $7.64 \pm 3.36$ & 0.71 \\
\hline & 13 & $35 / \mathrm{m} / \sqrt{ } / \mathrm{w}$ & $576.26 \pm 9.51$ & $23.62 \pm 5.54$ & 0.86 \\
\hline \multirow{4}{*}{ Cat-3 } & 14 & 31/f/x/teacher & $108.16 \pm 4.61$ & $1.17 \pm 0.69$ & 0.53 \\
\hline & 15 & 26/f/x/office & $133.72 \pm 5.23$ & $2.00 \pm 1.33$ & 0.16 \\
\hline & 16 & $42 / \mathrm{m} / \mathrm{x} /$ farmer & $348.01 \pm 6.01$ & $3.13 \pm 1.04$ & 0.11 \\
\hline & 17 & $25 / \mathrm{m} / \mathrm{x} / \mathrm{w}$ & $132.81 \pm 5.96$ & $1.05 \pm 0.22$ & -0.61 \\
\hline
\end{tabular}

* m- male, f- female, $\mathrm{x}$ - non-smoker, $\checkmark$ - smoker, pw- plant worker, w-other local work, OC- Occupation, R- Pearson“s” correlation coefficient.

Table 5. Inter-correlation between mercury data of selected matrices of human exposure-dose study in the vicinity of steel plant, Bhilai.

\begin{tabular}{llllll}
\hline Environmental Matrix & Category of subject & RPM-Hg & Blood-Hg & Urine-Hg & Milk-Hg \\
\hline \multirow{3}{*}{ Tambt-Hg } & Cat-1 & 0.55 & 0.51 & 0.44 & 0.26 \\
& Cat-2 & 0.76 & 0.91 & 0.67 & 0.92 \\
& Cat-3 & 0.05 & -0.06 & -7.66 & 0 \\
RPM-Hg & Cat-1 & & 0.88 & 0.69 & 0.49 \\
& Cat-2 & & 0.77 & 0.61 & 0.8 \\
& Cat-3 & & -0.045 & -7.155 & 0 \\
Blood-Hg & Cat-1 & & & 0.7 & 0.38 \\
& Cat-2 & & & 0.7 & 0.88 \\
& Cat-3 & & & & 0 \\
Urine-Hg & Cat-1 & & & & 0.87 \\
& Cat-2 & & & & 0.73 \\
\hline
\end{tabular}

Tambt-Hg: Total ambient mercury, RPM-Hg: mercury in respirable particulate matter.

than that occur in Category 3 of subjects of uncontaminated areas. All RPM-Hg levels have been observed to be higher than proposed permissible limits $\left(0.003 \mu \mathrm{g} \mathrm{m}^{-3}\right)$. Blood-Hg levels $(\mathrm{B}-\mathrm{Hg})$ have been observed to be very high compared to permissible limits $\left(3.0 \mu \mathrm{g} \mathrm{L}^{-1}\right)$ and comparable with previously reported average levels $\left(10-102 \mu \mathrm{g} \mathrm{L}^{-1}\right.$ ) (Adimado and Baah, 2002) (Fig. 6). In comparison to exposed particulate matrix and related biological fluids, blood-Hg levels have shown 4-5 times, 2-5 times and 1.5-3 times higher than
RPM-Hg, urine-Hg and breast milk-Hg levels, respectively. Category wise B-Hg of Category 1 has shown 5-6 times and 15-30 times higher levels compared to Category 2 and 3 respectively. Urine-Hg (U-Hg) levels have shown 32-95 times higher than permissible limits $\left(0.5 \mu \mathrm{g} \mathrm{L}^{-1}\right)$ compared to that 5.5-8.8 times higher for subjects belong to uncontaminated areas. Category wise, U-Hg levels of Category 1 has shown 2-2.5 times and 8-11 times higher than Category 2 and Category 3, respectively. Previous reported U-Hg 
Table 6. Regression data of $\mathrm{Hg}$ levels in human biological fluid with its exposure matrices around steel plant, Bhilai.

\begin{tabular}{|c|c|c|c|c|c|c|c|c|c|c|c|c|c|}
\hline \multirow{2}{*}{$\begin{array}{l}\text { Human fluid } \\
\text { matrix }\end{array}$} & \multirow{2}{*}{$\begin{array}{l}\text { Category of } \\
\text { Csubjects }\end{array}$} & \multicolumn{3}{|c|}{ Ambient-Hg } & \multicolumn{3}{|c|}{ RPM-Hg } & \multicolumn{3}{|c|}{ Soil-Hg } & \multicolumn{3}{|c|}{ GW-Hg } \\
\hline & & $R^{2}$ & Slope & intercept & $R^{2}$ & Slope & intercept & $R^{2}$ & slope & Intercept & $R^{2}$ & slope & Intercept \\
\hline \multirow{3}{*}{ Blood-Hg } & Cat-1 & 0.51 & 0.826 & 130.14 & 0.88 & 1.00 & 112.024 & 0.25 & 0.413 & 135.201 & 0.19 & 10.217 & 140.698 \\
\hline & Cat-2 & 0.91 & 0.852 & 17.064 & 0.77 & 0.84 & 22.51 & 0.46 & 1.04 & 27.47 & 0.24 & 12.38 & 36.7 \\
\hline & Cat-3 & 0.06 & 0.07 & 8.70 & 0.05 & 0.93 & 7.40 & 0.90 & 1.02 & 2.97 & 0.52 & 18.23 & 6.49 \\
\hline \multirow{3}{*}{ Urine-Hg } & Cat-1 & 0.88 & 0.53 & 30.24 & 0.70 & 0.62 & 19.47 & 0.38 & 3.97 & 30.46 & 0.28 & 30.80 & 32.17 \\
\hline & Cat-2 & 0.77 & 1.12 & 6.82 & 0.71 & 0.70 & 12.23 & 0.33 & 0.87 & 9.19 & 0.04 & 11.21 & 1.96 \\
\hline & Cat-3 & 0.04 & 0.08 & 3.59 & 0.17 & 1.88 & 0.90 & 0.60 & 0.49 & 0.32 & 0.46 & 11.21 & 1.96 \\
\hline \multirow{3}{*}{ Milk-Hg } & Cat-1 & 0.26 & 0.25 & 51.55 & 0.74 & 0.61 & 42.83 & 0.07 & 0.22 & 56.99 & 0.04 & 2.34 & 59.43 \\
\hline & Cat-2 & 0.92 & 0.63 & 26.38 & 0.80 & 1.23 & -11.70 & 0.39 & 0.82 & 28.25 & 0.35 & 7.65 & 32.12 \\
\hline & Cat-3 & - & - & - & - & - & - & - & - & - & - & - & - \\
\hline
\end{tabular}

GW-Hg: Mercury level in ground water used for drinking purpose.

levels in other regions has been observed to be in the range of 2.0-35.0 $\mu \mathrm{g} \mathrm{L}^{-1}$ (Adimado and Baah, 2002). Breast Milk-Hg $(\mathrm{BM}-\mathrm{Hg})$ levels of affected subjects from steel plant emissions have shown 13-21 times higher than permissible limits $\left(3.0 \mu \mathrm{g} \mathrm{L}{ }^{-1}\right)$ compared to subjects belong to uncontaminated areas that shown similar levels as reported for permissible limits. It has also been observed that BM-Hg is significantly higher than previously reported levels (10-25 $\mu \mathrm{g} \mathrm{L}{ }^{-1}$ ) (Sharma and Pervez, 2005; Saleh et al., 2003; and Srivastava, 2003).

\subsection{Dominance evaluation of major human exposure routes of mercury}

Inter-correlation coefficients between $\mathrm{Hg}$ data of selected exposure-biomarkers matrices have been presented in Table 5. Total ambient mercury levels (T-amt-Hg) has shown positive correlation with RPM-Hg and $\mathrm{Hg}$ levels measured in biomarkers human fluids of subjects belong to Category 2 compared to other category. RPM-Hg has shown higher strong positive correlation with all biomarkers matrices (B$\mathrm{Hg}, \mathrm{U}-\mathrm{Hg}$ and $\mathrm{BM}-\mathrm{Hg}$ ) in case of Category 1 compared to Category 2. Positive inter-correlation between biomarkers matrices has been obtained and justifies the similar source of accumulation of mercury.

Regression analysis of mercury data between identified exposure matrices and reported biomarkers among subjects affected by steel plant emissions alongwith subjects from uncontaminated areas has been presented in Table 6. Parameters (intercept and slope) of regression analysis were utilized to identify major dominating routes of mercury exposure among subjects residing in the vicinity of steel plant. It has been observed that mercury biomarker have shown different pattern of correlation with their exposure matrices among identified categories of subjects. B-Hg has shown that Category 1 is more tuned to RPM-Hg compared to Ambient-Hg, while it was reversed in case of Category 2. Category 3 have shown more prone towards soil- $\mathrm{Hg}$ compared to other ex- posure matrices. Plant workers of Category 1 have spent 8$10 \mathrm{~h}$ in workplace environment and exposed to fugitive emissions stored with high mercury content resulting in occurrence of higher correlation of personal RPM-Hg with B-Hg while subjects of Category 2 (local residents) were mostly exposed to environmental mercury through ambient route. Results have shown that personal RPM-Hg has given $23 \%$ contribution to B-Hg alongwith ambient-Hg of $10.82 \%$, soil$\mathrm{Hg}$ of $7.3 \%$ and GW-Hg of 3.5\%. Remaining 55\% contribution might be from other sources. Ambient-Hg has shown $57.49 \%$ contribution of $\mathrm{B}-\mathrm{Hg}$ in case of subjects belong to Category 2 with personal RPM contribution of $43.92 \%$, Soil$\mathrm{Hg}$ of $31.56 \%$ and $\mathrm{GW}-\mathrm{Hg}$ of $9.14 \%$. Subjects belong to Category 3 were residing in totally uncontaminated area from steel or any other industrial emissions. They have shown that soil- $\mathrm{Hg}$ is dominating route of B-Hg (64.64\%) alongwith GW-Hg of $22.73 \%$ due to their pattern of daily farming activities. Lower personal RPM-Hg contribution (11.90\%) compared to Soil-Hg is due to the fact that subjects spent their time at various microenvironments apart from farms.

Urine-Hg has also shown similar pattern of relationship with routes of exposure matrices as observed in case of B$\mathrm{Hg}$. Dominating exposure route of Urine-Hg for subjects of Category 1 has been observed to be personal RPM-Hg (51.94\%) compared to other routes (Ambient-Hg of $25.37 \%$, Soil-Hg of $24.32 \%$ and GW-Hg of $20.61 \%$ ). In case of Category 2 order of dominance of routes of urine- $\mathrm{Hg}$ is differ with B-Hg. After the highest contribution (64.21\%) from Ambient-Hg, Soil-Hg has shown dominance with contribution of $51.78 \%$ compared to personal RPM-Hg (35.83\%) and GW-Hg $(0.52 \%)$. It showed that Soil-Hg is one of the major contributors of Urine-Hg of subjects residing around the steel industry apart from steel plant emissions. Subjects from uncontaminated area (Category 3 ) have shown that urine-Hg is strongly affected by soil-Hg $(90.53 \%)$ through the personal RPM route $(73.37 \%)$. 
Beast milk mercury content (BM-Hg) has not shown major route of selected exposure matrices in case of Category 1. Ambient-Hg has shown $14.04 \%$ contribution alongwith personal RPM-Hg of $28.67 \%$, Soil- $\mathrm{Hg}$ of $5.1 \%$ and $\mathrm{GW}-\mathrm{Hg}$ of $1.0 \%$. In case of Category 2, dominating contribution through personal RPM has been obtained, while ambient has shown $33.04 \%$, Soil-Hg contributed $28.29 \%$ and GW-Hg has shown $18.84 \%$.

\section{Conclusions}

National Ambient Air Quality Standards in India has been presented in last decade and proposal of mercury as air borne pollutant has been included within last two years. Most of studies conducted in the field of air borne mercury monitoring are focused on regional scale and mainly covering urban areas. Studies around chlor-alkali industries and thermal power plants have also been conducted in few places of India. A major research project focused on spatiotemporal variation and impact assessment of anthropogenic mercury in the vicinities of selected coal-fired industries, sponsored by Ministry of Environment and Forests, Government of India has been completed and the work presented here is the part of that study. All sites around steel plant have shown higher concentration (10-150 folds) of Air-Hg and thousand folds of $\mathrm{PM}_{10}-\mathrm{Hg}$ compared to proposed standards. Most of individual measurements of $\mathrm{PM}_{10}-\mathrm{Hg}$ have been projected higher side from mean level, while inverse projection obtained in case of Air-Hg across the sites. The concentration of total mercury that found in vapour and particle phases of ambient air around steel industry has shown contrast scenario of partitioning of mercury between these two phases, compared to earlier studies conducted in India. Higher tendency of mercury to attach with particle phase around steel industry is due to higher presence of catalytic iron particles in ambient air. Regression analysis data have shown complex picture of exchange phenomena of mercury between air-particulate interphases across the sites. On taking prevailing wind sites, one site has shown negligible exchange of mercury between airparticle phases and explained that all particle bound mercury generated during combustion processes involved in steel industry. Other downwind site has shown significant exchange between air-particle inter-phases, statistically. This might be due to station of other potential sources of mercury which actually emitting vapour mercury along with catalytic components that responsible for conversion of vapour elemental mercury to particle bound inorganic mercury ions in air media. Highest exchange between air-particle phases has been evaluated to be at Site No. 3. Higher degree of spatiotemporal variation of ambient mercury around steel plant has explained complexity in its transportation, transformation and deposition pattern in geo-bio-environment around stationary combustion sources.
Higher occurrence of personal RPM and its mercury content at inhabitants of steel plant compared to control site has justified the significant impact of strong conversion of vapour mercury to particle phase. Human accumulation status of mercury among inhabitants of steel plant is at alarming situation. About ten folds higher mercury presence in blood, urine and breast milk compared to subjects belong to control site has been observed. Apart from personal RPM, water consumption has also shown significant route of pollutant exposure through ingestion. Personal RPM is the receptor of various routes of particulate matter from indoor microenvironments to ambient air. Ambient $\mathrm{PM}_{10}$ has also been chosen as one of the exposure route due to its potentiality around steel plant. Soils as major natural source of fine particulate in sub-tropical region have also been chosen as one of the major routes of exposure. It has been observed that workers of steel plant are majorly contaminated with personal RPM due to lots of fugitive emissions happen within plant premises. Subjects belong to control/uncontaminated site are mostly contaminated by soils and ground water.

Acknowledgement. Authors are grateful to Ministry of Environment and Forests, New Delhi for providing financial assistance and one of the authors (AK) is grateful to Pt. Ravishankar Shukla University, Raipur, and IIT, Mumbai, India for providing laboratory facilities.

Edited by: R. Ebinghaus

\section{References}

Adgate, J. L., Mongin, S. J., Pratt, G. C., Zhang, J., Field, M. P., Ramachandran, G. and Sexton, K.: Relationships between personal, indoor, and outdoor exposures to trace elements in $\mathrm{PM}(2.5)$, Sci Total Environ., 386, 21-32, 2007.

Adimado, A. A. and Baah, D. A.: Mercury in human blood, urine, hair, nail and fish from the Ankobra and Tano river basins in southwestern Ghana, Bull. Environ. Contam. Tox., 68, 339-346, 2002.

Airey, D.: Contributions from Coal and Industrial Materials to Mercury in Air, Rainwater and Snow, J. Geochem. Explor., 58(2-3), 223-229, 1997.

Al-Saleh, I., Shinwari N., Mashhour A., Gamal El-Din M., Abu Ghosh M., Shammasi Z., and Al-Nasser A.: Cadmium and mercury levels in Saudi women and its possible relationship with hypertension, Biol. Trace Elem. Res., 112(1), 13-29, 2006.

Borderieux, S., Wu, C.-Y., Bonzongo, J. C., and Powers, K.: Control of Elemental Mercury Vapor in Combustion Systems Using Fe2O3 Nanoparticles, Aeros. Air Qulty. Res., 4(1), 74-90, 2004.

Brook, J. R., Dann, T. F., and Burnett, R. T.: The relationship among TSP, $\mathrm{PM}_{10}, \mathrm{PM}_{2.5}$ and inorganic constituents of atmospheric particulates matter at multiple Canadian location, J. Air and Waste Manage. Assoc., 47, 2-19, 1997.

BSP: Production Profile of Bhilai Steel Plant, online available at: http://www.bee-india.nic.in/index.php? module=intro\&id=9, 2008. 
Cinnirella, S. and Pirrone, N.: Spatial and temporal distributions of mercury emissions from forest fires in Mediterranean region and Russian federation, Atmos. Environ., 40, 7346-7361, 2006.

Carpi, A.: Mercury from combustion sources: a review of the chemical species emitted and their transport in the atmosphere, Water Air Soil Pollut., 98, 241-254, 1997.

Conover, W. J.: Practical Nonparametric Statistics, 2nd Edition. Wiley, New York, 1980.

CPCB: Draft of ambient air quality criteria/standards: Annual Report. Center Pollution Control Board, http://74.125.153. 132/search?q=cache:HxZaFzIJmDEJ:www.cpcb.nic.in/latest/ 27.06.08\%2520Draft\%2520of\%2520Ambient\%2520Air\% 2520Quality $\% 2520$ Criteria\%2520Standards.doc+http: +//www.+cpcb.+nic.in/+latest/+27.06.08/Draft+of/+Ambient/ Air/+Quality/+Criteria/\&cd=1\&hl=en\&ct=clnk\&gl=in, 2008.

Crump, C., Bearer, C. F., Paschal, D. C., Rodenbaugh, D., and Etzel, R. A.: Mercury exposure in high school chemistry teachers, Arch. Environ. Contam. Tox., 31, 206-209, 1996.

Drasch, G., Horvart, M., and Stoeppler, M.: Mercury, in: Elements and their Compounds in the Environment, edited by: Merian, E., Anke, M., Ihnat, M., Stoeppler, M., 2nd edition, Wiley-VCH, Weinheim, 931-1005, 2004.

Envirotech. Background Material for Short Course on Ambient Air Quality and Management, Envirotech Center for Research and Development, New Delhi, 20-41, 2000.

Farzin, L., Amiri, M., Shams, H., Faghih Ahmadi, M. A., and Moassesi, M. E.: Blood levels of lead, cadmium and mercury in residents of Tehran, Biol. Trace Elem. Res., 123(1-3), 14-26, 2008.

Fitz-Simons, T. S.; Mathias, S., and Rizzo, M.: Analyses of 1999 PM data for the PM NAAQS review. Research Triangle Park, NC: U.S. Environmental Protection Agency, Office of Air Quality Planning and Standards, November 17. Available: http: //www.epa.gov/oar/oaqps/pm25/analyses.html (2 April 2002)], 2002.

Gadkari, N. and Pervez, S.: Source investigation of personal particulates in relation to identify major routes of exposure among urban residential, Atm. Environ., 41, 7951-7963, 2007.

Geller, M. D., Chang, M., Sioutas, C., Ostro, B. D., and Lipsett, M. J.: Indoor-outdoor relationship and chemical composition of fine and coarse particles in the southern California deserts, Atm. Environ., 36, 1099-1110, 2002.

Gilbert R. O.: Statistical Methods for Environmental Pollution Monitoring, Wiley Publication, New York, 4-60, 1987.

Gundacker, C., Pietschnig, B., and Whittmann, K. J.: Lead and mercury in breast milk, Pediatrics; 110(5), 873-878, 2002.

Hacon, S., Artaxo, P., Gerab, F., Yamasoe, M. A., Campos, R. C., Conti, L. F. and De Lacerda, L. D.: Atmospheric Mercury and Trace Elements in the Region of Alta-Floresta in the Amazon Basin, Water Air Soil Pollut., 80, 273-283, 1995.

Helsel, D. R and Hirsch, R. M.: Statistical Methods in Water Resources, Elsevier Science Publication, Amsterdam, 1992.

Kales, S. N. and Goldman, R. H.: Mercury exposure: current concepts, controversies, and a clinic's experience. J. Occup. Environ. Med., 44, 143-154, 2002.

Kathryn, R. M., Robert, P. C., and Rebecca, A. J.: Adult Women's Blood Mercury Concentrations Vary Regionally in the United States: Association With Patterns of Fish Consumption (NHANES 1999-2004), Environ. Hlth. Persp., 117(1), 47-53,
2009.

Katz, M.: Methods of air sampling and analysis, American Public Health Association (APHA), Interdisciplinary Book and Periodicals, Washington D.C , 1977.

Li, Z., Wang, Q. and Luo, Y.: Exposure of the urban population to mercury in Changchun city, Northeast China, Environ. Geochem. Hlth., 28, 61-66, 2006.

Linn, W. S., Gong, H. Jr., Clark, K. W., and Anderson, K. R.: Dayto-day particulate exposures and health changes in Los Angeles area residents with severe lung disease, J. Air \& Waste Manage. Assoc., 49, $\mathrm{PM}_{108}-\mathrm{PM}_{115}, 1999$.

Lu, J. Y. and Schroeder, W. H.: Sampling and determination of particulate mercury in ambient air: A review, Water Air Soil Pollut., 112, 279-295, 1999.

Mason, R. P., Fitzgerald, W. F., and Morel, M. M.: The Biological Cycling of Elemental Mercury: Anthropogenic Influence, Geochimica Acta, 58, 3191-3198, 1994.

Meng, Q. Y., Turpin, B. J., Lee, J. H., Polidori, A., Weisel, C. P., Morandi, M., et al.: How does infiltration behavior modify the composition of ambient PM2.5 in indoor spaces? An analysis of RIOPA data, Environ. Sci. Technol., 41, 7315-7321, 2007.

Montaser, A. and Golightiy, D. W.: Inductive coupled plasma in analytical atomic spectrometry, 2ND Edn. ,VCH Publication (New York), 1987.

Mukherjee, A.B., Zevenhoven, R., Bhattacharya, P., Sajwan, K.S. and Kikuchi, R.: Mercury flow via coal and coal utilization byproducts: A global persp., Res., Conserv. Recycl., 52, 571-591, 2008a.

Mukherjee, A. B., Bhattacharya, P., Sarkar, A., and Zavenhoven, R.: Mercury emissions from industrial sources in India and its effects in the environment. (Chapter-4), In:. Mercury Fate and Transport in the Global Atmosphere: Measurements, Models and Policy Implications, edited by: Pirrone, N. and Mason, R., Interim Report of the UNEP Global Mercury Partnership, Mercury Air Transport and Fate Research Partnership Area, 2008b.

Pacyna, J. M. and Keeler, G.: Sources of Mercury in the Arctic, Water Air Soil Pollut., 80, 621-632, 1995.

Pacyna, J. M.: Emission Inventories of Atmospheric Mercury from Anthropogenic Sources',in: Global and Regional Mercury Cycles: Sources, Fluxes and Mass Balances, edited by: Baeyens, W., Ebinghaus, R., and Vasiliev, O., NATO ARW, D. Reidel Publishing Company, Dordrecht, the Netherlands, 1996.

Pacyna, E. G., Pacyna, J. M., and Pirrone, N.: European emissions of atmospheric mercury from anthropogenic sources in 1995, Atm. Environ., 35(17), 2987-2996, 2001.

Pacyna, E. G. and Pacyna, J. M.: Global emissions of mercury from anthropogenic sources in 1995, Water Air Soil Pollut., 137, 149_ 165, 2002.

Pacyna, J. M., Pacyna, E. G., Steenhuisen, F., and Wilson, S.: Mapping 1995 Global Anthropogenic Emissions of Mercury, Atm. Environ., 37(S1), S109-S117, 2003.

Pacyna, E. G., Pacyna, J. M., Steenhuisen F., and Wilson S.: Global anthropogenic mercury emission inventory for 2000, Atm. Environ., 40, 4048-4063, 2006.

Pellizzari, E. D., Clayton, C. A., Rodes, C. E., Mason, R. E., Piper, L. L., Fort, B., Pfeifer, G. and Lynam, D.: Particulate matter and manganese exposures in Indianapolis, Indiana, J. Expo. Anal. Environ. Epidem., 11, 423-440, 2001.

Pirrone, N. and Kathryn, M.: Dynamics of mercury pollu- 
tion on regional and global scales: Atmospheric processes and human exposures around the world, Springer publication, doi:10.1007/b105709; Chapter-1, 1-21, 2005.

Pirrone, N. and Mason, R.: Mercury Fate and Transport in the Global Atmosphere: Measurements, Models and Policy Implications, Interim Report of the UNEP Global Mercury Partnership, Mercury Air Transport and Fate Research Partnership Area, 2008.

Pirrone, N., Ferrara R., Hedgecock, I. M., Kallos, G., Mamane, Y., Munthe, J., Pacyna, J. M., et al. :Dynamic processes of mercury over the Mediterranean region: results from the Mediterranean Atmospheric Mercury Cycle System (MAMCS) project, Atm. Environ., 37(S1), 21-39, 2003.

Pirrone, N., Pacyna, J. M., and Barth, H.: Atmospheric mercury research in Europe, Atm. Environ., 35(17), 2997-3006, 2001.

Pirrone, N., Costa, P., Pacyna, J. M., and Ferrara, R.: Mercury Emission to the Atmosphere from Natural and Anthropogenic Sources in the Mediterranean Region, Atm. Environ., 35, $2997-$ 3006, 2001a.

Pirrone, N., Keeler, G. J., and Nriagu, J. O.: Regional differences in worldwide emissions of mercury to the atmosphere, Atm. Environ., 30, 2981-2987, 1996.

Richard, J., Thomson, B., George, M., and Lazzy, P.: Analysis of Selected Elements in Atmospheric Particulate Matter by Atomic Absorption, New Letter, 9(3), 1-9, 1970.

Riley, K.: Midwest Hazardous Substance Research Center Outreach Programs for Communities, www.egr.msu.edu/tosc/Summaries/ Alpena_CKD_Site.shtml, 2001.

Rizzo, M. and Pinto, J. P.: Initial Characterization of Fine Particulate Matter $\left(\mathrm{PM}_{2.5}\right)$ Collected by the National Federal Reference Monitoring Network, Paper Presented at: 94th annual conference \& exhibition of the Air and Waste Management Association, June, Orlando, FL. Pittsburgh, PA: Air and Waste Management Association, 2001.

Roosli, M.: Spatial variability of air pollutants in the Basel area and carcinogenic and non-carcenogenic health risk, Ph.D. Thesis, University of Basel, Basel, Switzerland, 2001.

Rojas-Bracho, L., Suh, H. H., and Koutrakis, P.: Relationships among personal, indoor, and outdoor fine and coarse particle concentrations for individuals with COPD, J. Expo. Anal. Environ. Epidem., 10, 294-306, 2000.

Saleh, I. A., Shinwari, N. and Mashhour, A.: Heavy metal concentrations in the breast milk of Saudi women, Biol. Trace Elem. Res., 96, 21-37, 2003.

Sarnat, S. E., Coull, B. A., Ruiz, P.A., Koutrakis, P., and Suh, H. H.: The influences of ambient particle composition and size on particle infiltration in Los Angeles, CA, residences, J. Air Waste Manage. Assoc., 56, 186-196, 2006.

Schuster, P. F., Krabbenhoft, D. P., Naftz, D. L., Cecil, L .D., Olson, M. L., and Dewild, J. F.: Atmospheric Mercury Deposition During the last 270 years: A Glacial Ice Core Record of Natural and Anthropogenic Sources, Environ. Sci. Technol., 36, 2303-2310, 2002.
Sharma R. K.: Characterization and impact assessment of emitted dusts in selected environment, Ph.D, Thesis, Govt. V.Y.T. Post graduate autonomous college, Durg, India, 2002.

Sharma, R. K. and Pervez, S.: Toxic metals status in human blood and breast milk samples in an integrated steel plant environment in central India, Environ. Geochem. Hlth., 27(1), 39-45, 2005.

Solomon, G. M. and Weiss, P. M.: Chemical Contaminants in Breast Milk: Time Trends and Regional Variability, Environ. Hlth. Persp., 110, A339-A347, 2002.

Srivastava, R. C.: Guidance and Awareness Raising Materials under new UNEP Mercury Programs (Indian Scenario), Guidance Material Under New UNEP Mercury Programme 2003; Center for Environment Pollution Monitoring and Mitigation, Lucknow, 2003.

Themelis, N. J. and Gregory, A. F.: Mercury Emissions from High Temperature Sources in the NY/NJ Hudson- Rarital Basin, Proceeding of NAWTEC 10, American Society of Mechanical Engineers, 205-215, 2002.

USEPA.: Integrated science assessment for particulate matter: First external review draft, EPA/600/R-08/139, 2008; National Center for Environmental Assessment, US Environmental Protection Agency, Research Triangle Park, NC, 171-188, 2008.

USEPA: Air Quality Criteria for Particulate Matter, Vol-I, EPA/600/P-95/001aF, Office of the Research and Development, United States Environmental Protection Agency, Washington DC, 2-5, 1996.

USEPA: Mercury study report to Congress. Vol. V. Health effects of mercury and mercury compounds. EPA-452/R-97-007, 1997; Office of Air Quality Planning and Standards, United Sates Environmental Protection Agency, USA, 1997.

USEPA: Third External Review Draft of Air Quality Criteria for Particulate Matter, volume-I and II . Unites States Environmental Protection Agency, Washington DC, April, 2002.

USEPA: Fourth External Review Draft of Air Quality Criteria for Particulate Matter.June-2003, EPA/600/P-99/2aD,US Environmental Protection Agency, Washington DC, 2003.

Volkovic, V.: Trace element in coal,Volume-II, CRC Press Publication, Florida, 51-83,1983.

Walcher F. J.: Standard methods of chemical analysis, 6TH Edn., Vol. 2, D. Van Nostrand Publication, Canada, 1963.

Warner, N. R., Jonathan, L., Karen, H., and Frank, F.: Drinking water quality in Nepal's Kathmandu Valley: A survey and assessment of selected controlling site characteristics, J. Hydrol., 16(2), 1431-2174, 2008.

WHO.: Elemental mercury and inorganic mercury compounds: human health aspects. Concise international chemical assessment document 50, Geneva, World Health Organization, 2003. 